The University of Maine

DigitalCommons@UMaine

Marine Sciences Faculty Scholarship

School of Marine Sciences

8-17-2007

\title{
Modeling Responses of Diatom Productivity and Biogenic Silica Export to Iron Enrichment in the Equatorial Pacific Ocean
}

Fei Chai

University of Maine - Main, fchai@maine.edu

M.S. Jiang

Y. Chao

R. C. Dugdale

F. Chavez

See next page for additional authors

Follow this and additional works at: https://digitalcommons.library.umaine.edu/sms_facpub

\section{Repository Citation}

Chai, Fei; Jiang, M. S.; Chao, Y.; Dugdale, R. C.; Chavez, F.; and Barber, R., "Modeling Responses of Diatom Productivity and Biogenic Silica Export to Iron Enrichment in the Equatorial Pacific Ocean" (2007). Marine Sciences Faculty Scholarship. 75.

https://digitalcommons.library.umaine.edu/sms_facpub/75 
Authors

Fei Chai, M. S. Jiang, Y. Chao, R. C. Dugdale, F. Chavez, and R. Barber 


\title{
Modeling responses of diatom productivity and biogenic silica export to iron enrichment in the equatorial Pacific Ocean
}

\author{
F. Chai, ${ }^{1}$ M.-S. Jiang, ${ }^{1,2}$ Y. Chao, ${ }^{3}$ R. C. Dugdale, ${ }^{4}$ F. Chavez, ${ }^{5}$ and R. T. Barber ${ }^{6}$ \\ Received 7 August 2006; revised 17 May 2007; accepted 11 June 2007; published 17 August 2007.
}

[1] Using a three-dimensional physical-biogeochemical model, we have investigated the modeled responses of diatom productivity and biogenic silica export to iron enrichment in the equatorial Pacific, and compared the model simulation with in situ (IronEx II) iron fertilization results. In the eastern equatorial Pacific, an area of $540,000 \mathrm{~km}^{2}$ was enhanced with iron by changing the photosynthetic efficiency and silicate and nitrogen uptake kinetics of phytoplankton in the model for a period of 20 days. The vertically integrated $\mathrm{Chl} a$ and primary production increased by about threefold 5 days after the start of the experiment, similar to that observed in the IronEx II experiment. Diatoms contribute to the initial increase of the total phytoplankton biomass, but decrease sharply after 10 days because of mesozooplankton grazing. The modeled surface nutrients (silicate and nitrate) and $\mathrm{TCO}_{2}$ anomaly fields, obtained from the difference between the "iron addition" and "ambient" (without iron) concentrations, also agreed well with the IronEx II observations. The enriched patch is tracked with an inert tracer similar to the SF6 used in the IronEx II. The modeled depth-time distribution of sinking biogenic silica (BSi) indicates that it would take more than 30 days after iron injection to detect any significant BSi export out of the euphotic zone. Sensitivity studies were performed to establish the importance of fertilized patch size, duration of fertilization, and the role of mesozooplankton grazing. A larger size of the iron patch tends to produce a broader extent and longer-lasting phytoplankton blooms.

Longer duration prolongs phytoplankton growth, but higher zooplankton grazing pressure prevents significant phytoplankton biomass accumulation. With the same treatment of iron fertilization in the model, lowering mesozooplankton grazing rate generates much stronger diatom bloom, but it is terminated by $\mathrm{Si}(\mathrm{OH})_{4}$ limitation after the initial rapid increase. Increasing mesozooplankton grazing rate, the diatom increase due to iron addition stays at minimum level, but small phytoplankton tend to increase. The numerical model experiments demonstrate the value of ecosystem modeling for evaluating the detailed interaction between biogeochemical cycle and iron fertilization in the equatorial Pacific.

Citation: Chai, F., M.-S. Jiang, Y. Chao, R. C. Dugdale, F. Chavez, and R. T. Barber (2007), Modeling responses of diatom productivity and biogenic silica export to iron enrichment in the equatorial Pacific Ocean, Global Biogeochem. Cycles, 21, GB3S90, doi:10.1029/2006GB002804.

\footnotetext{
${ }^{1}$ School of Marine Sciences, University of Maine, Orono, Maine, USA ${ }^{2}$ Now at Environmental, Earth and Ocean Sciences Department, University of Massachusetts-Boston, Boston, Massachusetts, USA.

${ }^{3}$ Jet Propulsion Laboratory, California Institute of Technology, Pasadena, California, USA.

${ }^{4}$ Romberg Tiburon Center, San Francisco State University, Tiburon, California, USA.

${ }^{5}$ Monterey Bay Aquarium Research Institute, Moss Landing, California, USA.

${ }^{6}$ Nicholas School of the Environment and Earth Sciences Marine Laboratory, Duke University, Beaufort, North Carolina, USA.

\section{Introduction}

[2] Equatorial Pacific surface water, with its excess nitrate and phosphate but low chlorophyll, has been characterized as a high-nitrate, low-chlorophyll (HNLC) region. Observed phytoplankton biomass is at a relatively lower level than expected given the optimal euphotic light conditions [Barber, 1992]. In addition to the grazing control by zooplankton on phytoplankton biomass accumulation [Frost and Franzen, 1992; Landry et al., 1997], the present low supply of iron, via dust, to the HNLC regions (equatorial Pacific, Southern Ocean, and North Pacific) may limit phytoplankton ability to take up excess nitrate and phosphate [Martin, 1990]. It has been proposed that the low $\mathrm{Si}(\mathrm{OH})_{4}$ concentration in the equatorial Pacific may limit 
diatom growth as well [Dugdale and Wilkerson, 1998; Dugdale et al., 2006] owing to low silicate supply [Ku et al., 1995]. Although the phytoplankton biomass is dominated by picoplankton in the equatorial Pacific [Chavez et al., 1996], a strong role for diatoms in controlling new production was indicated by the first silicate pump model [Dugdale and Wilkerson, 1998]. Diatoms, although a minor component of the phytoplankton, accounted for most of the $\mathrm{NO}_{3}$ uptake and the smaller phytoplankton used mainly regenerated $\mathrm{NH}_{4}$. The $\mathrm{Si}(\mathrm{OH})_{4}$ concentration within the euphotic zone is relatively low and shows little variability as compared to $\mathrm{NO}_{3}$, especially in the central equatorial Pacific. This would establish a possible chemostat-like condition [Dugdale and Wilkerson, 1998; Dugdale et al., 2006] whereby $\mathrm{Si}(\mathrm{OH})_{4}$ regulates diatom growth. How silicate uptake by diatoms may change in responses to variation of iron supply is still not clear.

[3] In situ mesoscale iron-enrichment experiments conducted in the HNLC regions showed that low levels of additional iron dramatically increase the productivity and growth of both small phytoplankton and diatoms as well as the zooplankton that graze on both size classes of phytoplankton, enhance macronutrient uptake, and decrease the partial pressure of $\mathrm{CO}_{2}$ [Coale et al., 1996; Boyd et al., 2000; de Baar et al., 2005; Barber and Hiscock, 2006]. Logistic constraints on the length of time the research vessels can remain with the fertilized patch have limited these experiments to about 30 days, not long enough for significant changes to occur at high trophic levels. In addition, what is not yet well documented is the fate of the iron-stimulated productivity of phytoplankton (mainly diatoms) once it leaves from the euphotic zone [Ridgwell, 2000; Charette and Buesseler, 2000], or how much of it is exported vertically to the deep ocean.

[4] Owing to the technical difficulty of measuring carbon and BSi export directly in the fertilized patches, the in situ iron-enrichment experiments did not document the fate of the new primary productivity [Buesseler and Boyd, 2003; de Baar et al., 2005]. Ecosystem modeling provides an alternative means to test the detailed interaction between iron and silicon cycle in the HNLC regions for short-term consequences [Fujii et al., 2005], and many long-term aspects of the iron fertilization process [Jiang and Chai, 2004], and to estimate export carbon from the surface to the deep ocean [Gnanadesikan et al., 2003]. Most importantly, modeling the responses of diatom productivity and the silicon cycle to iron addition would improve our understanding of the role of silicate and iron in determining global carbon cycle, for present-day conditions as well as past glacial-interglacial cycles [Dugdale et al., 2004].

\section{Model Description}

\subsection{Physical Model}

[5] The physical model is the Climate System Model (CSM) ocean component, which is a modified version of the Modular Ocean Model (MOM). We have configured the model for the Pacific Ocean and the model performance has been reported by Li et al. [2001]. The Pacific Ocean model domain is between $45^{\circ} \mathrm{S}$ and $65^{\circ} \mathrm{N}, 100^{\circ} \mathrm{E}$ and $70^{\circ} \mathrm{W}$, with realistic geometry and topography. The longitudinal resolu- tion of the equatorial Pacific is $2^{\circ}$ everywhere, while the latitudinal is $0.5^{\circ}$ within $10^{\circ} \mathrm{S}$ and $10^{\circ} \mathrm{N}$, tapering off to $2^{\circ}$ at high latitude. There are 40 vertical layers, with 23 levels located in the upper $400 \mathrm{~m}$. In the regions near the two closed northern and southern walls, a sponge layer with a region of $10^{\circ}$ from the walls is applied for temperature, salinity and nutrients. The treatment of the sponge layer consists of a decay term $\kappa\left(\mathrm{T}^{*}-\mathrm{T}\right)$ in the temperature equation $\left[\kappa\left(\mathrm{S}^{*}-\mathrm{S}\right)\right.$ for salinity equation, $\kappa\left(\mathrm{N}^{*}-\mathrm{N}\right)$ for nutrient equations], which restored it to the observed temperature $\mathrm{T}^{*}$ (salinity $\mathrm{S}^{*}$, nutrients $\mathrm{N}^{*}$ ) field at the two closed walls. The value of $\kappa$ varies smoothly from $1 / 30$ day $^{-1}$ at the walls to zero 10 degrees away them.

[6] Surface forcing can be separated into momentum, heat, and light for photosynthesis. Momentum fluxes are calculated with the zonal and meridional wind speeds from the Comprehensive Ocean-Atmosphere Data Set (COADS). Heat flux calculation includes short wave radiation, outgoing long wave radiation, and both sensible heat and latent heat. Surface light intensity $\left(\mathrm{I}_{\mathrm{o}}\right)$ is converted from the monthly mean COADS short wave radiation $\left(\mathrm{R}_{\mathrm{s}}\right), \mathrm{I}_{\mathrm{o}}=$ $0.5 * \mathrm{R}_{\mathrm{s}}$. Salinity is restored to the National Oceanographic Data Center (NODC) climatology monthly mean salinity at sea surface [Levitus et al., 1994; Levitus and Boyer, 1994].

\subsection{Biological Model}

[7] In the present study, we use a one-dimensional (1-D) CoSINE model (Carbon, $\mathrm{Si}(\mathrm{OH})_{4}$, Nitrogen Ecosystem) [Chai et al., 2002; Dugdale et al., 2002] coupled with a 3-dimensional (3-D) ocean circulation model [ $\mathrm{Li}$ et al., 2001] to study the modeled responses of diatom productivity and biogenic silica export to iron enhancement in the equatorial Pacific. The 1-D CoSINE model has been tested against the JGOFS data over the equatorial Pacific and is capable of reproducing the Low-Silicate, High-Nitrate, Low-Chlorophyll (LSHNLC) conditions in the equatorial Pacific. The 1-D CoSINE model was also used to investigate the influence of equatorial diatom processes on $\mathrm{Si}$ deposition and atmospheric $\mathrm{CO}_{2}$ cycles at glacial-interglacial timescales [Dugdale et al., 2004].

[8] The CoSINE model consists of ten compartments describing two size classes of phytoplankton and zooplankton, detritus nitrogen and detritus silicon, silicate, total $\mathrm{CO}_{2}$ and two forms of dissolved inorganic nitrogen: nitrate and ammonium (Figure 1). P1 represents small, easily grazed phytoplankton whose specific growth varies, but whose biomass is regulated by micrograzers (Z1) and whose daily net productivity is largely remineralized [Chavez et al., 1991; Landry et al., 1995, 1997]. P2 represents diatoms $(>10 \mu \mathrm{m}$ in diameter) that makes up high biomass blooms and contributes disproportionately to sinking flux as ungrazed production or large fecal pellets [Smetacek, 1985; Bidigare and Ondrusek, 1996]. The diatoms have the potential to grow fast under optimal nutrient conditions $\left(\mathrm{N}, \mathrm{Si}\right.$ and $\mathrm{Fe}$ concentrations $\gg \mathrm{K}_{\mathrm{S}}$, Michaelis-Menten constant for nutrient uptake) [Coale et al., 1996]. Z1 represents small micrograzers whose specific growth rate are similar to $\mathrm{P} 1$ phytoplankton, and whose grazing rate is density dependent [Landry et al., 1997]. Z2 represents larger mesozooplankton that graze on diatoms and detritus 




Figure 1. Carbon, $\mathrm{Si}(\mathrm{OH})_{4}$, nitrogen ecosystem (CoSINE) model structure. See the text for details about the model configuration.

nitrogen $(\mathrm{DN})$ and prey on $\mathrm{Z} 1$. The detrital pool is split into detrital nitrogen (DN) and silicon (DSi or as BSi in the text discussion) in order to balance supplies of nitrogen and silicon through the upwelling and vertical mixing separately. The detrital silicon (DSi) sinks faster than the detrital nitrogen (DN). The linkage of the carbon cycle to the ecosystem model is through the consumption and remineralization of assimilated nutrients based upon the nitrogen changes in the water column by using Redfield stoichiometric ratios. The $\mathrm{C} / \mathrm{N}$ ratio of $117 / 16(=7.3)$ of Anderson and Sarmiento [1994] is used. The role of iron in the model is simulated through two photosynthetic parameters: lightlimited photosynthesis is described by $\alpha$, and $\mathrm{I}_{\mathrm{k}}$ gives a measure of the irradiance at light saturation; see more detail of iron treatment in the CoSINE model in section 3.

[9] Below the euphotic zone, sinking particulate organic matter is converted to inorganic nutrients by a regeneration process similar to the one used by Chai et al. [1996] and Jiang et al. [2003], in which organic matter decays to ammonium, and then is nitrified to $\mathrm{NO}_{3}$. The BSi dissolution rate varies significantly with area and depth and depends strongly on the water temperature, among other factors [Nelson et al., 1995; Ragueneau et al., 2000]. For simplicity, we only considered temperature effects and chose the following formulation:

$$
\text { BSi Dissolution }=(0.19 \mathrm{~T} / 25+0.01) \mathrm{X} \exp (0.069(\mathrm{~T}-25))
$$

[10] This formulation has a similar shape to the Arrhenius function used by Gnanadesikan [1999]. This dissolution scheme has a rate of 0.2 day $^{-1}$ at temperature of $25^{\circ} \mathrm{C}$, which is on the higher end of the observed $0.01 \sim 0.2$ day $^{-1}$ in the Sargasso Sea [Brzezinski and Nelson, 1995] and 0.1 day $^{-1}$ reported in the neighboring Peruvian coast [Nelson et al., 1981]. The dissolution rate decreases to 0.05 day $^{-1}$ at $200 \mathrm{~m}$ where the annual mean temperature ranges from $14^{\circ}$ to $16^{\circ} \mathrm{C}$ within equatorial band and the background rate of $0.01 \mathrm{day}^{-1}$ at depth. Therefore the dissolution rate at $200 \mathrm{~m}$ is about one fourth of the surface value with a timescale of 20 days. With a particle sinking velocity of $20 \mathrm{~m}$ day $^{-1}$, these imply a roughly $100 \mathrm{~m}$ length scale at the surface and about $400 \mathrm{~m}$ within the thermocline. The relationship of the BSi dissolution rate with temperature and its impact on the silicon cycling have been investigated with a series of model sensitivity studies by Fujii and Chai [2005]. The proposed BSi dissolution rate calculation (equation (1)) is consistent with the results by Fujii and Chai [2005]. The detailed equations and parameters used for the CoSINE model were presented in the papers by Chai et al. [2002, 2003] and Jiang et al. [2003]. All the parameter values used in this simulation are the same as those used by Jiang et al. [2003].

\subsection{Model Integration}

[11] The physical model is initialized with World Ocean Atlas climatological January temperature and salinity with zero velocities [Levitus et al., 1994; Levitus and Boyer, 1994]. Nutrients (nitrate and silicate) are initialized with World Ocean Atlas climatological annual mean values [Levitus et al., 1993]. Total $\mathrm{CO}_{2}$ is initialized by interpolation of the World Ocean Circulation Experiment (WOCE) data set. For other components in the biological model, they are assigned with $0.25 \mathrm{mmol} \mathrm{m}^{-3}$ at the surface, decreasing exponentially with a scale length of $110 \mathrm{~m}$, which is the depth of euphotic zone. 
[12] From the initial conditions, the coupled physicalbiological model is forced with the climatological monthly mean COADS forcing. The ten ecosystem governing equations are solved simultaneously with the physical model. The physical-biogeochemical model is integrated with the COADS climatological monthly forcing for 10 years from the initial conditions. During this 10 -year period, the model achieves a quasi-equilibrium state of annual cycle in the upper ocean [Chai et al., 2003; Jiang et al., 2003].

\section{Experiment Design}

[13] In the eastern equatorial Pacific, iron-enrichment experiments are simulated by changing the photosynthetic efficiency that is based upon observations made in the iron enrichment experiments (e.g., IronEx I and IronEx II) [Martin et al., 1994; Coale et al., 1996]. Lindley et al. [1995] and Lindley and Barber [1998] suggested that iron directly regulates photosynthesis of phytoplankton in surface waters of the HNLC region in the equatorial Pacific Ocean. The photosynthetic performance of phytoplankton in our model, besides of nitrogen and silicate regulations, is described with two light related parameters: light-limited photosynthesis is described by $\alpha$, and $\mathrm{I}_{\mathrm{k}}$ gives a measure of the irradiance at light saturation. These two parameters are used in the following three equations that control the productivity of two phytoplankton groups:

$$
N P S I=\mu 1_{\max } \frac{N O_{3}}{K_{N O_{3}}+N O_{3}} e^{-\psi N H_{4}}\left(1-e^{-\frac{I}{I_{k}}}\right) P 1
$$

where NPS1 is $\mathrm{NO}_{3}$ uptake by small phytoplankton, $\mu 1_{\text {max }}=1.8$ day $^{-1}$ (maximum specific growth rate of small phytoplankton), $\psi=8.0\left(\mathrm{mmol} \mathrm{m} \mathrm{m}^{-3}\right)^{-1}$ (ammonium inhibition parameter), $K_{n o 3}=1.0 \mathrm{mmol} \mathrm{m}^{-3}$ (half-saturation for nitrate uptake by S1), $\alpha=0.025\left(\mathrm{~W} \mathrm{~m}^{-2}\right)^{-1}$ day $^{-1}$ (initial slope of P-I curve), P1 is small phytoplankton concentration, $\mathrm{NO}_{3}$ is the nitrate concentration, and $\mathrm{I}$ is the irradiance.

$$
R P S I=\mu 1_{\max } \frac{N H_{4}}{K_{N H_{4}}+N H_{4}}\left(1-e^{-\frac{I}{I l_{k}}}\right) P 1,
$$

where RPS1 is $\mathrm{NH}_{4}$ uptake by small phytoplankton, $K_{N H 4}=$ $0.05 \mathrm{mmol} \mathrm{m}^{-3}$ (half-saturation for ammonium uptake by $\mathrm{P} 1$ ).

$$
P P S 2=\mu 2_{\max } \frac{\mathrm{Si}(\mathrm{OH})_{4}}{K_{\mathrm{Si}(\mathrm{OH})_{4}}+\mathrm{Si}(\mathrm{OH})_{4}}\left(1-e^{-\frac{I}{12_{k}}}\right) P 2,
$$

where $\mu 2_{\max }=2.0$ day $^{-1}$ (the potential maximum specific diatom growth rate), $K_{\mathrm{si}(\mathrm{OH}) 4}=3.5 \mathrm{mmol} \mathrm{m}^{-3}$ (half-saturation for $\mathrm{Si}(\mathrm{OH})_{4}$ uptake by $\left.\mathrm{P} 2\right)$, and $\mathrm{P} 2$ is diatom concentration.

$$
\begin{gathered}
I 1_{k}=\frac{\mu 1_{\max }}{\alpha} \\
I 2_{k}=\frac{\mu 2_{\max }}{\alpha},
\end{gathered}
$$

where PPS2 is the silicate uptake by diatoms, or the portion of the total primary production contributed by diatoms. Beside silicate uptake, diatoms also take up nitrogen (both $\mathrm{NO}_{3}$ and $\mathrm{NH}_{4}$ ). In the CoSINE model, the ratio of silicate to the total nitrogen uptake (both nitrate and ammonium) by diatoms is 1 to 1 . Thus

$$
\text { PPS2 }=\text { NPS2 }+ \text { RPS2, }
$$

where NPS2 is $\mathrm{NO}_{3}$ uptake by diatoms (or new production by diatoms), which is calculated similar to the equation (2). RPS2 is $\mathrm{NH}_{4}$ uptake by diatoms (or regenerated production by diatoms), which is calculated similar to the equation (3).

[14] The total primary production (PP) in carbon unit will be

$$
\mathrm{PP}=7.3 *(\text { NPSI }+ \text { RPSI }+ \text { PPS2 })
$$

The primary production is converted to carbon unit from nitrogen unit by applying a fixed $\mathrm{C} / \mathrm{N}$ ratio of 7.3. All above parameter values are the same as those used in the modeling work by Jiang et al. [2003], which has documented the changes of parameter values from one-dimension model [Chai et al., 2002] to three-dimensional model [Jiang et al., 2003, Table 1].

[15] According to the iron addition experiment results [Lindley et al., 1995; Lindley and Barber, 1998], $\alpha$ doubled inside the iron-enriched patch relative to outside the patch where it remained unchanged, while $\mathrm{I}_{\mathrm{k}}$ was the same inside and outside the patch. To simulate the enhanced photosynthetic performance with additional iron in the model, we double $\alpha\left(0.025\right.$ to 0.05 day $\left.^{-1}\left(\mathrm{~W} \mathrm{~m}^{-2}\right)^{-1}\right)$ and keep $\mathrm{I}_{\mathrm{k}}$ and $I 2_{\mathrm{k}}$ the same in the model. As a consequence of doubling $\alpha$ and holding $\mathrm{I}_{\mathrm{k}}$ constant, $\mu 1_{\max }$ (the potential maximum specific picoplankton growth rate) is doubled from 1.8 to 3.6 (day $^{-1}$ ), $\mu 2_{\max }$ (the potential maximum specific diatom growth rate) is also doubled from 2.0 to 4.0 day $^{-1}$, since $\mu 1_{\max }$ equals to $\alpha \times \mathrm{I} 1_{\mathrm{k}}$ and $\mu 2_{\max }$ equals to $\alpha \times \mathrm{I} 2 \mathrm{k}$.

[16] Using a higher maximum specific growth rate is equivalent to removing or greatly reducing all physiological limitations due to micronutrients such as iron. By keeping all other model parameters the same, including the grazing formulation, the effect of removing a physiological constraint on photosynthetic performance or growth can be distinguished from the effects of physical processes and grazing. Similar techniques, but with a nitrogen-based ecosystem model, were used by Chai et al. [1996, 1999] to investigate iron limitation and zooplankton grazing in the equatorial Pacific. Denman and Pena [1999] used a fourcomponent NPZD model and the same approach as Chai et al. [1996] to simulate the effects of iron limitation in the northeast subarctic Pacific Ocean. Fujii et al. [2005] used another one-dimensional ecosystem model and the same technic of iron treatment to investigate similarity and difference of iron fertilization experiments in several HNLC regions. Jiang and Chai [2005] also used the same treatment for the effects of iron in the CoSINE model to investigate the latitudinal asymmetry of surface nutrients and $\mathrm{pCO} 2$ in the central and eastern equatorial Pacific. 

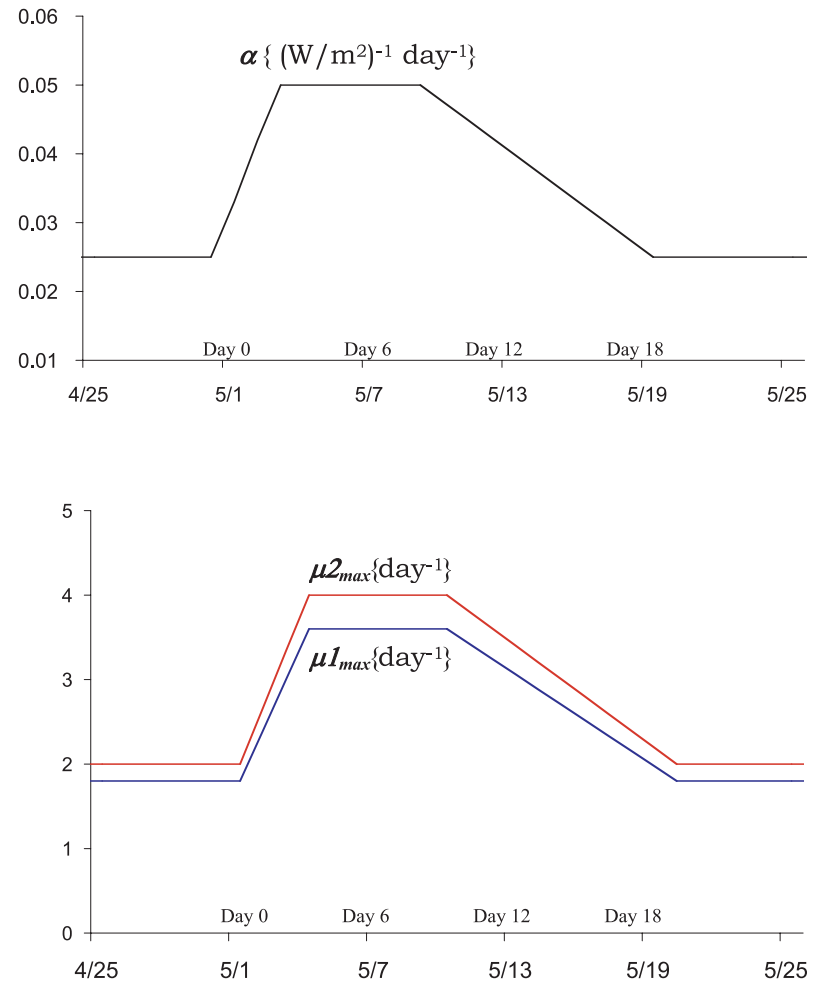

Figure 2. (top) Temporal variation of $\alpha$ (initial slope of P-I curve), the unit is $\left(\mathrm{W} / \mathrm{m}^{2}\right)^{-1}$ day $^{-1}$. (bottom) Temporal variation of $\mu 2_{\max }$ (the maximum potential growth rate of diatoms, red line) and $\mu 1_{\max }$ (the maximum potential growth rate of small phytoplankton, blue line); the unit is day $^{-1}$. Day 0 is the starting day of the iron fertilization, corresponding to climatological mean conditions of 1 May.

[17] The spatial area for the enhanced photosynthetic parameters is $0.25^{\circ} \mathrm{S}-3.75^{\circ} \mathrm{S}$ and $101^{\circ} \mathrm{W}-115^{\circ} \mathrm{W}$, a total area of approximately $540,000 \mathrm{~km}^{2}$. The size of the modeled iron patch is about 10,000 times larger than the patches created during the IronEx I and IronEx II experiments. The larger size of the modeled iron patch results from the nature of the current coarse model resolution, which does not allow us to investigate the small patch dynamics adequately. Different size of iron patch and their impact on phytoplankton response have been tested as a set of sensitivity studies.

[18] Temporal changes for $\alpha, \mu 1_{\max }$ and $\mu 2_{\max }$ are shown in Figure 2. The starting date of the modeled iron experiment is 1 May of the 11 th year model simulation. During the first three days, $\alpha, \mu 1_{\max }$ and $\mu 2_{\max }$ gradually increase to the double of the original values. Since we do not model iron concentration and cycling explicitly in this model, we kept both $\alpha$ and $\mu_{\max }$ for the highest values for 7 days, between day 4 and day 10, to eliminate iron related limitation in the model, so phytoplankton can grow at the maximum potential rate. Between day 11 and day 20, $\alpha$, $\mu 1_{\max }$ and $\mu 2_{\max }$ gradually decrease back to the original values. After 20 days, the tested parameters are reset back to the values used in the standard model run. We changed the model parameters for 20 days mainly to mimic the length of
IronEx II. By doing so, we can evaluate the modeled responses during this 20 days period by comparing with the data. The modeled chlorophyll concentration is derived from the phytoplankton biomass concentration ( $\mathrm{mmol} \mathrm{N} \mathrm{m}^{-3}$ ), converted to $\mathrm{mg} \mathrm{m}^{-3}$ using a nominal gram chlorophyll to molar nitrogen ratio of 1.64 , corresponding to a chlorophyll to carbon mass ratio of 1:50 and a $\mathrm{C}: \mathrm{N}$ molar ratio of 7.3 .

\section{Results and Discussion \\ 4.1. Model Results and Data Comparisons}

[19] The physical-biological model reproduces the annual mean nitrate and silicate concentrations in the equatorial Pacific, and compared well with the observed climatological nutrients (Figure 3). In general, the surface $\mathrm{NO}_{3}$ concentration in the eastern part of the high-nutrient tongue is about $2 \mathrm{mmol} \mathrm{m}^{-3}$ higher than $\mathrm{Si}(\mathrm{OH})_{4}$, as evident in the modeled results and World Ocean Atlas 98 [Conkright et al., 1998]. The pattern of modeled surface nutrients is in good agreement with the data except for the southeast corner where the modeled $\mathrm{NO}_{3}$ concentration is much higher than the observed. The low light acclimation assumption consistent with general Fe-limitation conditions may impose too strong of a constraint in this area because persistent upwelling may provide more iron for phytoplankton growth [Jiang et al., 2003].

[20] The physical-biological model reproduces integrated chlorophyll concentration and primary production as compared with the observed values outside the IronEx II patch [Coale et al., 1996] (Figure 4, blue lines). Jiang et al. [2003] presented more detailed comparison between the modeled primary production and the observed climatological values by Barber et al. [1996]. Overall, the physicalbiological model produces many features similar to the observations in the equatorial Pacific. After changing $\alpha$ and $\mu_{\max }$ inside the patch, Chl $a$ increases and reaches a maximum at day 5 (red lines in Figure 4). The magnitude of the modeled integrated Chl $a$ increase, $49.8 \mathrm{mg} / \mathrm{m}^{2}$ at the peak, is similar to the observed IronEx II Chl $a$ maximum, $41.8 \mathrm{mg} / \mathrm{m}^{2}$. The modeled integrated primary production reaches a peak of $250 \mathrm{mmol} \mathrm{C} / \mathrm{m}^{2} /$ day at day 4 , whereas the observed IronEx II value is $204 \mathrm{mmol} \mathrm{C} / \mathrm{m}^{2} /$ day. The model captures both the magnitude and timing of chlorophyll increase and productivity, and compares well with the observations.

[21] There are a few notable differences between observed and modeled fields. For example, the modeled maximum increases of Chl $a$ and primary production tend to occur a couple of days earlier than in IronEx II, and modeled responses tend to be stronger than the data. This could be due to the temporal change of the model parameters ( $\alpha$ and $\left.\mu_{\max }\right)$ that is slower than the phytoplankton physiological responses during the IronEx II, which was within the first 24 hours [Lindley and Barber, 1998; Coale et al., 1996], where the model parameters reached the maximum potential growth rate at the day 3 after the experiment started. The second factor might contribute to this difference is the size of the iron patch. The modeled patch is about 10,000 times larger than the iron patch during the IronEx II, $540,000 \mathrm{~km}^{2}$ 


\begin{tabular}{cccccccc}
0 & 2 & 4 & 6 & 8 & 10 & 12 & 14 \\
\hline & 1 & 1 & $\perp$ & 1 & $\perp$ & 1
\end{tabular}
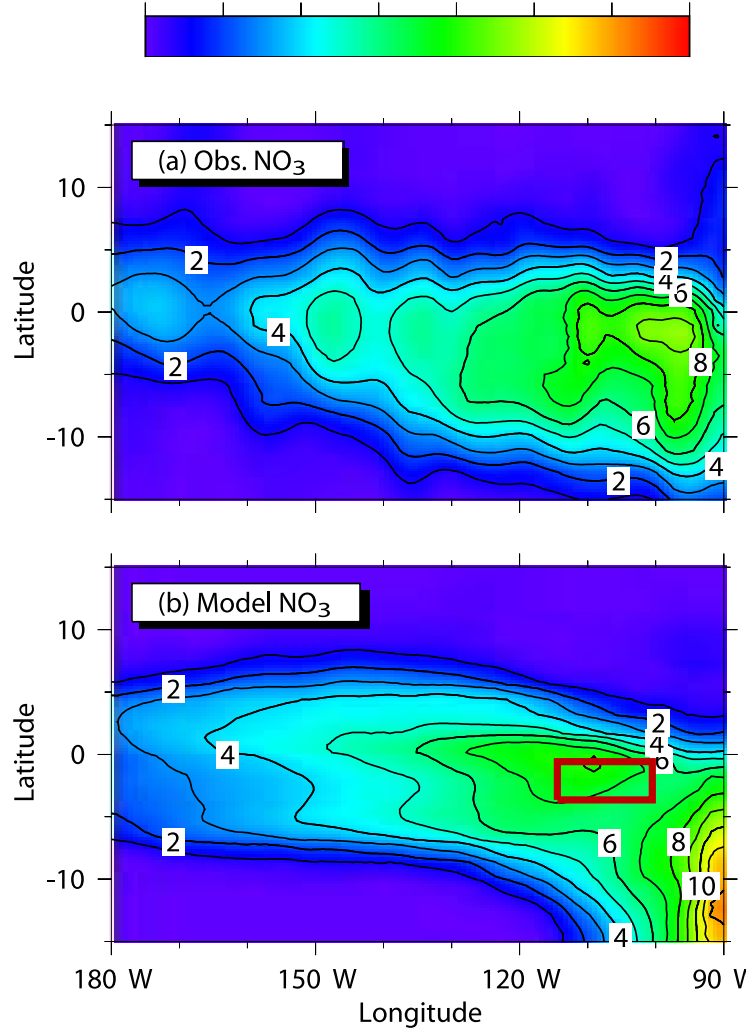


Figure 3. Comparisons of modeled annual mean of surface nutrients (unit: $\mathrm{mmol} \mathrm{m}^{-3}$ ) in eastern equatorial area and climatological data from WOA98. (a) Observed $\mathrm{NO}_{3}$. (b) Modeled $\mathrm{NO}_{3}$. (c) Observed $\mathrm{Si}(\mathrm{OH})_{4}$. (d) Modeled $\mathrm{Si}(\mathrm{OH})_{4}$. The red box in Figures $3 \mathrm{~b}$ and $3 \mathrm{~d}$ is the region where the model parameters are changed for the iron enrichment experiment.

versus $64 \mathrm{~km}^{2}$. Averaging the modeled chlorophyll and primary production over such large area might not yield fair comparison between the model results and the data. The present coarse resolution circulation model could not be used to investigate the patch dynamics, which affects how to define the iron patch during the course of iron fertilization. The third factor that could cause the model and data difference is the simplification of the mesozooplankton growth cycle in the model. While the model has a constant daily zooplankton growth rate, in nature mesozooplankton growth occurs in "steps" as eggs hatch and nauplii recruit into the population. Incorporating detailed mesozooplankton life cycle submodel is beyond the scope of this modeling investigation. Despite the simple treatment of mesozooplankton dynamics, the modeled increase of $\mathrm{Chl}$ $a$ and primary production compare well with the IronEx II results [Coale et al., 1996].

[22] While most phytoplankton groups respond positively to iron fertilization, diatoms show the strongest increases [Barber and Hiscock, 2006]. In the model, photosynthetic efficiencies were increased equally for diatoms and small phytoplankton (Figure 2), resulting in different responses of both phytoplankton and zooplankton functional groups (Figure 5). The top two plots show $\mathrm{NO}_{3}$ and $\mathrm{Si}(\mathrm{OH})_{4}$ concentration averaged within the iron patch. The $\mathrm{Si}(\mathrm{OH})_{4}$ concentration (Figure 5b) reaches the minimum value of $1.5 \mathrm{mmol} / \mathrm{m}^{3}$ around day 10 , which could limit diatom potential growth. Within the first 5 days of the modeled experiment, the diatom biomass increases more than a factor of 5 , from 0.1 to $0.58 \mathrm{mmol} \mathrm{m}^{-3}$ (Figure $5 \mathrm{c}$ ). However, the diatom populations decrease rapidly on day 5 owing to grazing by mesozooplankton; mesozooplankton biomass reaches a maximum on day 7 (Figure 5d). During the first 3 days of the model experiment, the small phytoplankton populations increase slightly, from 0.14 to $0.27 \mathrm{mmol} \mathrm{m}^{-3}$ (Figure 5e); but they decrease after day 5 owing to an increase in microzooplankton, with a minimum value of $0.12 \mathrm{mmol} \mathrm{m}^{-3}$ for small phytoplankton reached on day 6 and a maximum value of $0.87 \mathrm{mmol} \mathrm{m}^{-3}$ for microzooplankton reached on day 5 (Figures 5e and 5f). Mesozooplankton graze on microzooplankton as well as diatoms and they reduce microzooplankton to a minimum on day 8 . This results in a relaxation of grazing pressure on the small phytoplankton, which reaches a second maximum on day 10 with a surface value of $0.26 \mathrm{mmol} \mathrm{m}^{-3}$, about twice the initial value of $0.14 \mathrm{mmol} / \mathrm{m}^{3}$. The combined phytoplankton biomass produces a double maximum as seen from the integrated primary production in the patch (Figure $4 \mathrm{~b}$ ), in which the diatoms dominate the first maximum and the picoplankton are responsible for the second. 

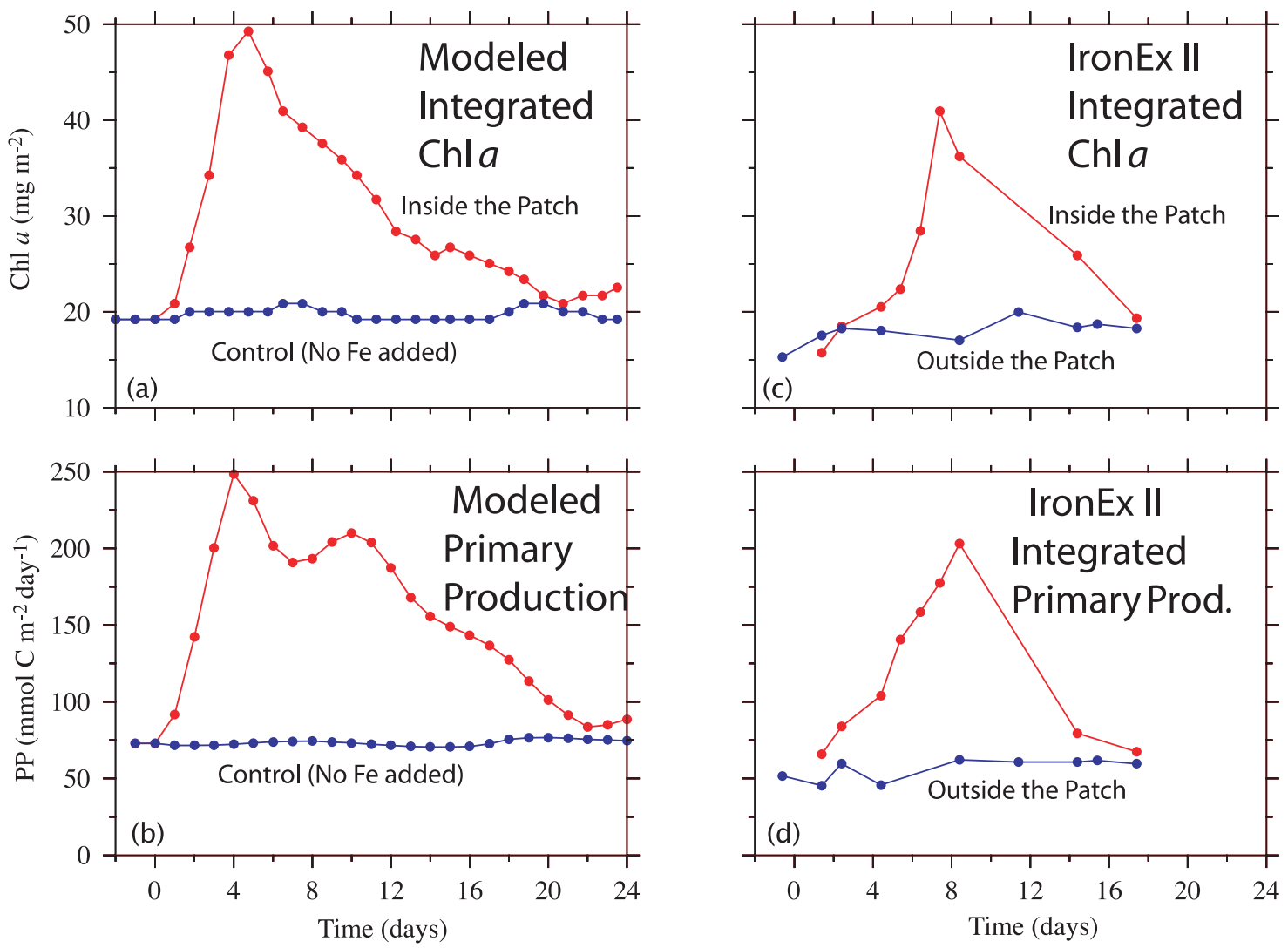

Figure 4. Comparison between the modeled Fe enrichment and IronEx II results. (left) Modeled (a) integrated $(0-110 \mathrm{~m}) \mathrm{Chl} a$ and (b) primary production. (right) IronEx II integrated $(0-110 \mathrm{~m})(\mathrm{c}) \mathrm{Chl}$ $a$ and (d) primary production. The day 0 here corresponds to 1 May, starting date of the experiment. The red lines are averaged values inside the patch with elevated Fe-related growth parameters, and the blue lines are the background values. The background values are obtained from the same patch area without iron fertilization, for example, the normal model simulation. The units and scales are the same for the modeled and observed results.

[23] Because of the similar growth and grazing rates of picoplankton and microzooplankton, there is tight coupling and the biomass of microzooplankton and picoplankton tend to oscillate with about 3 days periodicity. This cycle repeats itself during the modeled iron fertilization experiment, but the amplitude of the oscillation becomes smaller over time (Figures 5e and 5f). This is likely due to increases in diatoms, which alter the mesozooplankton grazing preferences between diatoms and microzooplankton. The microzooplankton grazing pressure on picoplankton is then altered. Such complicated multiple predator-prey interactions, documented previously in the one-dimensional model by Chai et al. [2002], would not be easy to document with the limited observational data [Landry et al., 2000; Barber and Hiscock, 2006].

\subsection{Role of Mesozooplankton Grazing: A Sensitivity Investigation}

[24] In order to test the role of mesozooplankton grazing on diatom biomass accumulation, two model sensitivity simulations have been conducted. Following the same iron treatment, we also double the mesozooplankton maximum grazing rate $\mathrm{G} 2{ }_{\max }\left(0.53 \mathrm{day}^{-1}\right.$ for the default run) to 1.06 day $^{-1}$ during the period of iron addition (1 May to 20 May), and this experiment is labeled as "Grazing $\times$ 2.0 ". The second grazing experiment is to reduce the mesozooplankton maximum grazing rate $\mathrm{G} 2$ max by $50 \%$ from $0.53 \mathrm{day}^{-1}$ to $0.265 \mathrm{day}^{-1}$ for the same period as iron added, and this experiment is labeled as "Grazing $\times$ 0.5 ". With three model simulations, "Default", "Grazing $\times$ 2.0 ", and "Grazing $\times 0.5$ ", we compare the modeled surface nutrients and plankton concentration inside the iron patch, Figure 6. With the reduced grazing rate ("Grazing $\times$ 0.5 " experiment), the increase of diatom biomass due to iron addition is significantly higher (reach a maximum value of $2.25 \mathrm{mmol} / \mathrm{m}^{3}$ at day 4) than the "Default" simulation $\left(0.58 \mathrm{mmol} / \mathrm{m}^{3}\right.$ at day 4$)$ (Figure 6c). Even with such reduced grazing pressure, the diatom biomass still starts to decrease at day 5 , which results from $\mathrm{Si}(\mathrm{OH})_{4}$ limitation. At day 5, the modeled surface $\mathrm{Si}(\mathrm{OH})_{4}$ concentration reaches the minimum value of $0.65 \mathrm{mmol} / \mathrm{m}^{3}$, and

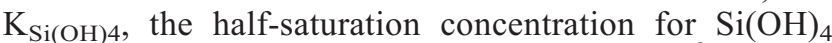
uptake by diatoms in the model is $3.5 \mathrm{mmol} / \mathrm{m}^{3}$. So, the 


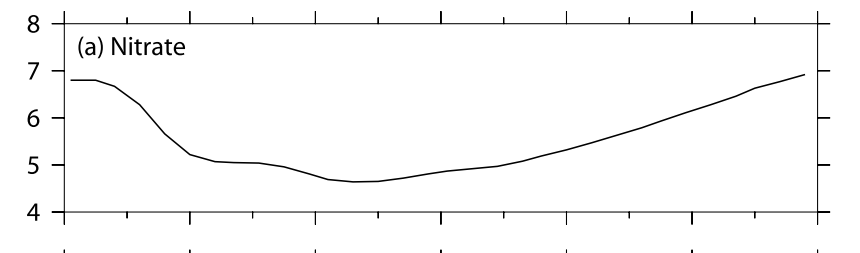

pressure on microzooplankton, small phytoplankton start to increase after day 10 (Figure 6e).

[25] With the same treatment of iron addition in the model, mesozooplankton grazing plays an important role in determining the net increase of total phytoplankton
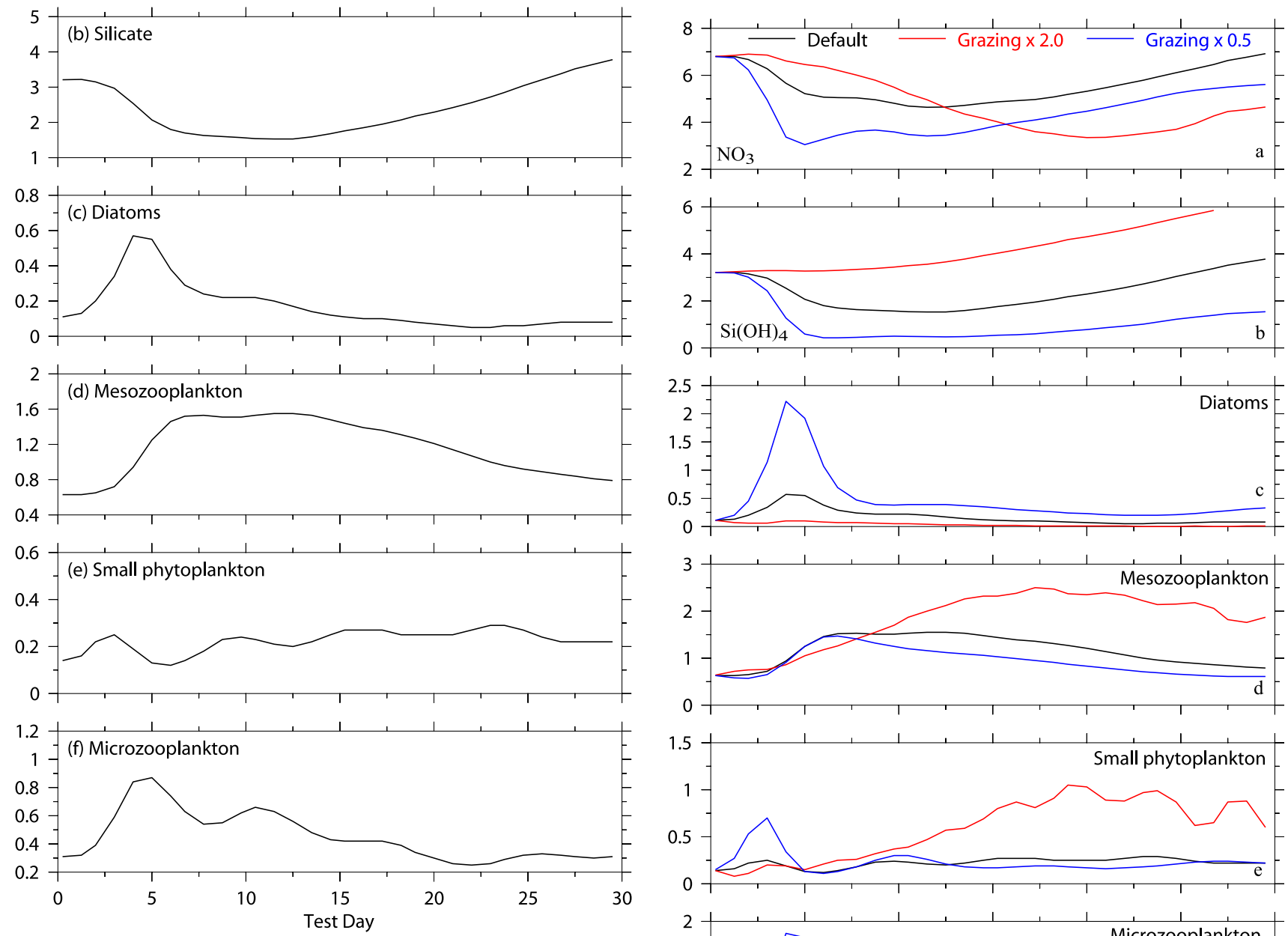

Figure 5. Modeled surface responses of nutrients and plankton to iron enrichment over a 30-day period. The modeled nutrients and plankton concentrations are averaged inside the iron patch, which is defined with the inert tracer in the model, and unit is $\mathrm{mmol} / \mathrm{m}^{3}$ for all six plots.

uptake of $\mathrm{Si}(\mathrm{OH})_{4}$ by diatoms after day 5 starts to decrease, which slows down diatoms growth in spite of higher growth rate of diatoms stimulated by the iron addition. On the other hand, with higher grazing rate ("Grazing $\times 2.0$ " experiment), the diatom biomass stays almost the same regardless of the changes of growth parameters due to the effects of iron addition (Figure 6c). The higher mesozooplankton grazing rate results higher mesozooplankton biomass, which reaches the maximum value of $2.5 \mathrm{mmol} / \mathrm{m}^{3}$ at day 17 (Figure 6d). Again, the increase of mesozooplankton biomass would alter grazing preferences between diatoms and microzooplankton, which in turn affects small phytoplankton concentration. With higher mesozooplankton grazing

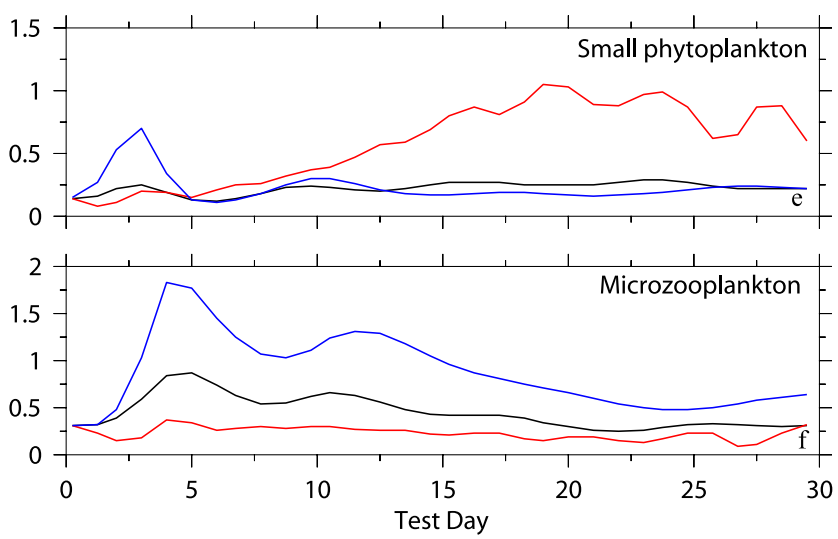

Figure 6. Modeled surface responses of nutrients and plankton as sensitivity simulations to different mesozooplankton grazing experiments. "Default" is the standard model simulation with iron fertilization (black line); "Grazing $\times 2.0 "$ (red line) experiment doubles the mesozooplankton maximum grazing rate $\mathrm{G} 22_{\max }\left(0.53\right.$ day $^{-1}$ for the default run) to 1.06 day $^{-1}$ during the period of iron addition ( 1 to 20 May); "Grazing $\times 0.5$ " reduces the mesozooplankton maximum grazing rate $\mathrm{G} 2{ }_{\max }$ by $50 \%$ from 0.53 day $^{-1}$ to 0.265 day $^{-1}$ for the same period as iron added. The modeled nutrients and plankton concentrations are averaged inside the iron patch, which is defined with the inert tracer in the model, and unit is $\mathrm{mmol} / \mathrm{m}^{3}$ for all six plots. 
biomass. With lower mesozooplankton grazing rate, diatom bloom induced by iron addition is much stronger, but it is terminated by $\mathrm{Si}(\mathrm{OH})_{4}$ limitation after the initial rapid increase. With higher mesozooplankton grazing rate, the diatom increase due to iron addition stays at minimum level, but small phytoplankton tend to increase. Changing mesozooplankton biomass would alter the grazing preferences between diatoms and microzooplankton, which can then result in phytoplankton concentrations. For the model grazing sensitivity experiments, the modeled mesozooplankton biomass tends to increase too rapidly after the increase of the maximum grazing rate, and similar results have been documented with the 1D model study [Chai et al., 2002]. In nature, the increase in mesozooplankton biomass appears to lag the increase in diatom biomass by about a week, or slightly longer [Monger et al., 1997]. Including the mesozooplankton reproduction cycle (e.g., juveniles, adults) would certainly alter predator-prey interactions in the model.

\subsection{Spatial Responses and Movement of the Iron Patch}

[26] The size of the modeled patch is about 10,000 times larger than the iron patch during the IronEx II, $540,000 \mathrm{~km}^{2}$ versus $64 \mathrm{~km}^{2}$. On the basis of size alone the movement and behavior of the modeled patch would likely be different from the IronEx II patch. The spatial patterns within the large modeled patch were analyzed, given that the physical properties are not uniformly distributed. The time series of surface anomaly fields, obtained from the difference between the "iron addition" and "ambient" (without iron) concentrations (Figure 7), were examined. By day 5, the surface phytoplankton biomass anomaly reaches a maximum value of $0.4 \mathrm{mmol} \mathrm{m}^{-3}$ located in the northern portion of the patch (Figure 7a). The surface phytoplankton biomass anomaly decreases after day 5 , but the signature of iron fertilization can be observed until day 60 as the center of the patch moves southwest from its original position. The patch identified by the anomaly in surface phytoplankton biomass is similar to the other surface anomaly fields, such as $\mathrm{NO}_{3}$, $\mathrm{Si}(\mathrm{OH})_{4}$ and $\mathrm{TCO}_{2}$ (Figures $7 \mathrm{~b}, 7 \mathrm{c}$ and $\left.7 \mathrm{~d}\right)$. The maximum model drawdown of surface nitrate and silicate are around 3.8 and $2.7 \mathrm{mmol} \mathrm{m}^{-3}$, respectively, and the maximum decrease in surface $\mathrm{TCO}_{2}$ is $22.4 \mathrm{mmol} \mathrm{m}^{-3}$. The modeled surface nutrient and $\mathrm{TCO}_{2}$ anomaly fields agree with the observed surface decreases of nutrients and $\mathrm{TCO}_{2}$ [Steinberg et al., 1998] (Table 1). The modeled maximum drawdown of nutrients and $\mathrm{TCO}_{2}$ tend to be lower than the observed, and this could be due to the size of iron patch created in the model that is 10,000 times large than the patch generated during the IronEx II. Both the modeled and observed $\mathrm{Si}(\mathrm{OH})_{4}$ concentration is about $1 \mathrm{mmol} \mathrm{m}$ during the peak of the diatom bloom, which indicates the termination of the diatom bloom (or slowdown of the diatom growth) could be potentially due to the low $\mathrm{Si}(\mathrm{OH})_{4}$ concentration. The minimum of $\mathrm{NO}_{3}$ concentration during the peak of the phytoplankton bloom is 5 and $7 \mathrm{mmol} \mathrm{m}^{-3}$ in the model and the observed, respectively. This suggests that $\mathrm{NO}_{3}$ is a not factor to terminate iron induced phytoplankton bloom. The model simulated nutrients and $\mathrm{TCO}_{2}$ anomalies due to iron addition indicate longer effects than just 20 to 30 days, which is a typical time period of iron fertilization experiments.

[27] The movement and reshaping of the patch are controlled primarily by the circulation and diffusion processes, and the chemical and biological processes inside the patch follow the movement of the patch accordingly. To document the movement of the modeled patch, an inert tracer (IT), which is controlled only by physical circulation and diffusion, was introduced in the model. The behavior of this IT is similar to the SF6 used during the iron fertilization experiments [Law et al., 1998]. The initial IT concentration is assigned a value of 100 for the top $50 \mathrm{~m}$ of the water column, and the time series of the surface IT concentration shows the impact of mesoscale circulation and diffusion processes in both horizontal and vertical directions (Figure 7e). The center of the patch moves from $2^{\circ} \mathrm{S}$ and $108^{\circ} \mathrm{W}$ on day 1 to $4.5^{\circ} \mathrm{S}$ and $112^{\circ} \mathrm{W}$ on day 40 with an estimated speed of 50 to $60 \mathrm{~km}$ day $^{-1}$, which is comparable with the patch movement during IronEx II [Coale et al., 1996]. The current model resolution is $2^{\circ}$ in longitude and $0.5^{\circ}$ in latitude near the equator, and is not eddy-resolving, so the patch movement reflects the mean flow patterns for the region without small-scale eddy dynamics.

\subsection{Size of the Iron Patch: Model Sensitivity Simulations}

[28] In order to address the size of iron patch, its movement and their impact on phytoplankton bloom dynamics, we have designed a set of sensitivity studies by varying the size of iron patch. Beside the normal simulation with $7 \times$ 7 grid cells patch $\left(540,000 \mathrm{~km}^{2}\right)$, model simulations with $2 \times 2,4 \times 4$, and $10 \times 10$ grid cells patch have been carried out, which represent area of 44,000 $\mathrm{km}^{2}, 176,000 \mathrm{~km}^{2}$, $1,100,000 \mathrm{~km}^{2}$, respectively. The treatment of model responses to iron addition within the patch is the same as the normal model simulation, for example, following same the temporal changes for $\alpha, \mu 1_{\max }$ and $\mu 2_{\max }$ inside the iron patch. The general direction of patch movement are very similar regardless of their size, the center of the patch moves toward the southwest direction during the first 60 days simulation (Figure 8). The change of the patch shape is also very similar among these four model simulations, with the main axis of the patch tilts from southwest to northeast. Such movement and shape change of the patch are consistent with the local currents. On the other hand, smaller patches $(2 \times 2$ and $4 \times 4$ grid cells patch $)$ tend to have lower IT concentration at day 60 , which is due to the initial released amount of IT is much less in the $2 \times 2$ grid cells patch comparing to the $10 \times 10$ grid cells patch simulation. Also, the center of the patch in $2 \times 2$ and $4 \times 4$ grid cells simulations is not well defined at day 60 . This is mainly due to the diffusion influencing smaller patches faster and stronger than its impact on the larger patches.

[29] Different size of iron patch affects nutrients and plankton dynamics differently, especially spatial extent and duration of phytoplankton bloom. During the early phase of iron fertilization between day 0 and day 10 , the increase of phytoplankton biomass in the center of the patch is very similar among difference iron patch experiments, for 

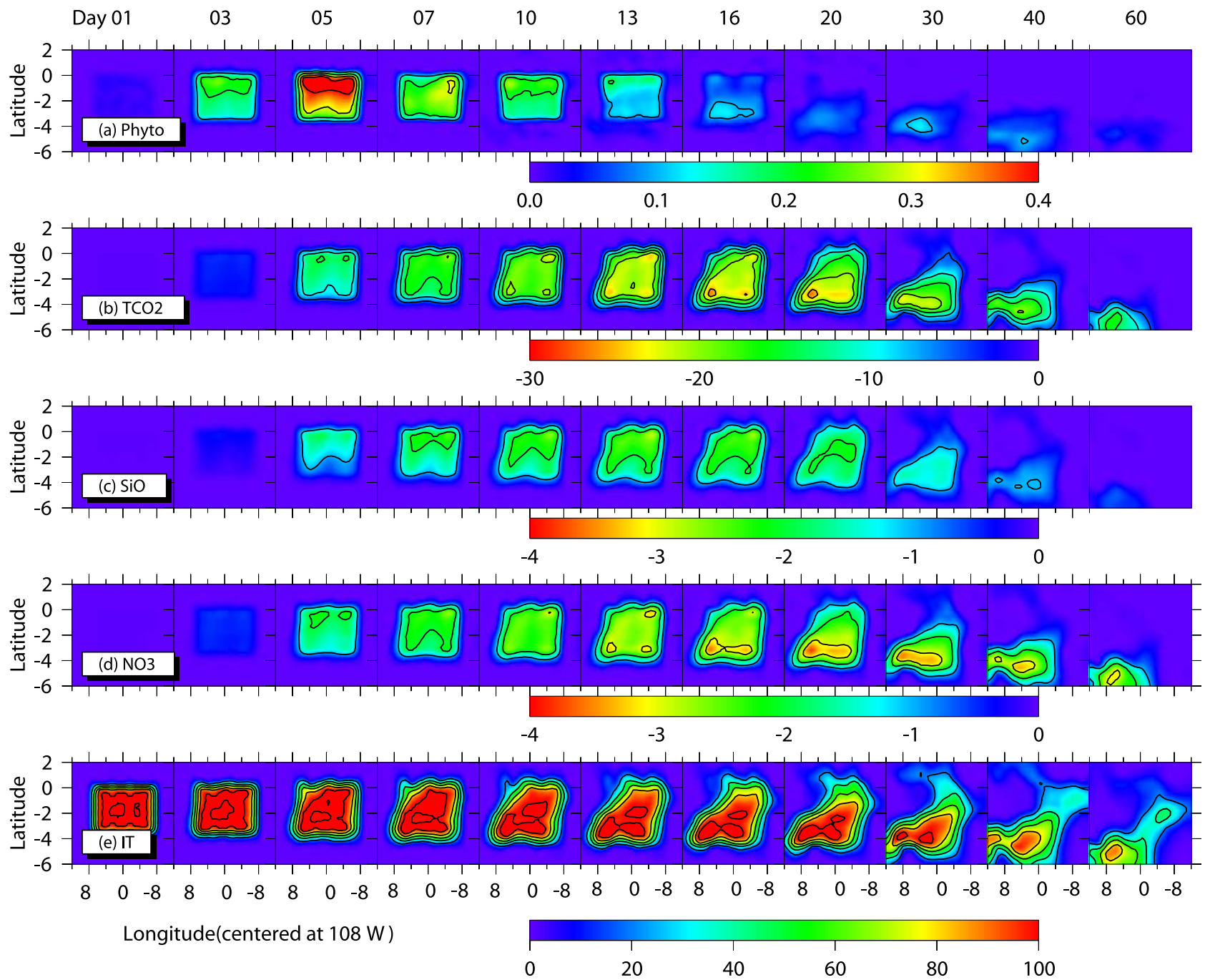

Figure 7. Temporal and spatial variations of the modeled surface anomaly fields, which are obtained from the difference between the "iron addition" and "ambient" (without iron) concentrations. (a) The modeled phytoplankton anomaly, the unit is $\mathrm{mmol} / \mathrm{m}^{3}$; red means positive, with phytoplankton increase due to iron enrichment. (b) $\mathrm{TCO}_{2}$ anomaly, the unit is $\mathrm{mmol} / \mathrm{m}^{3}$, the red color means negative that is drawdown by phytoplankton growth. (c) $\mathrm{Si}(\mathrm{OH})_{4}$ anomaly, the unit is $\mathrm{mmol} / \mathrm{m}^{3}$, red means negative. (d) $\mathrm{NO}_{3}$ anomaly, the unit is $\mathrm{mmol} / \mathrm{m}^{3}$, red means negative. (e) An inert tracer (IT), only controlled by circulation and diffusion processes, no unit; the value is 100 inside the patch at the beginning of the iron enrichment.

example, the net increase, or the phytoplankton biomass anomaly due to iron addition, is about $0.4 \mathrm{mmol} / \mathrm{m}^{3}$ at day 5 for all four model simulations (Figure 9). This is mainly due to the treatment of iron effects is kept same for all four experiments with the maximum increase of phytoplankton growth parameters between day 3 and day 10 (Figure 2). During the decay phase of phytoplankton bloom (after day 16), phytoplankton biomass anomaly with the larger iron patches $(7 \times 7$ and $10 \times 10$ grid cells patch $)$ tend to reach a broader extent and last longer comparing to the smaller patch experiments (Figure 9). After day 20, all the phytoplankton growth parameters inside the patch are returned to the normal value, which indicates the end of iron effects. However, phytoplankton biomass increase expands into much broader spatial domain in the larger patch experiments $(7 \times 7$ and $10 \times 10$ grid cells patch $)$. Similarly to the IT field, the phytoplankton biomass are

Table 1. Comparison Between the Modeled and Observed Drawdown of Nutrients and $\mathrm{TCO}_{2}$ Due to Iron Fertilization

\begin{tabular}{lccc}
\hline & $\begin{array}{c}\text { Maximum } \mathrm{NO}_{3} \\
\text { Drawdown, } \\
\text { mmol m }^{-3}\end{array}$ & $\begin{array}{c}\text { Maximum Si(OH) } \\
\text { Drawdown, } \\
\text { mmol m }^{-3}\end{array}$ & $\begin{array}{c}\text { Maximum } \mathrm{TCO}_{2} \\
\text { Drawdown, } \\
\text { mmol m }^{-3}\end{array}$ \\
\hline Modeled & 3.8 & 2.7 & 22.4 \\
Observed & 4.0 & 4.0 & 27.0 \\
\hline
\end{tabular}




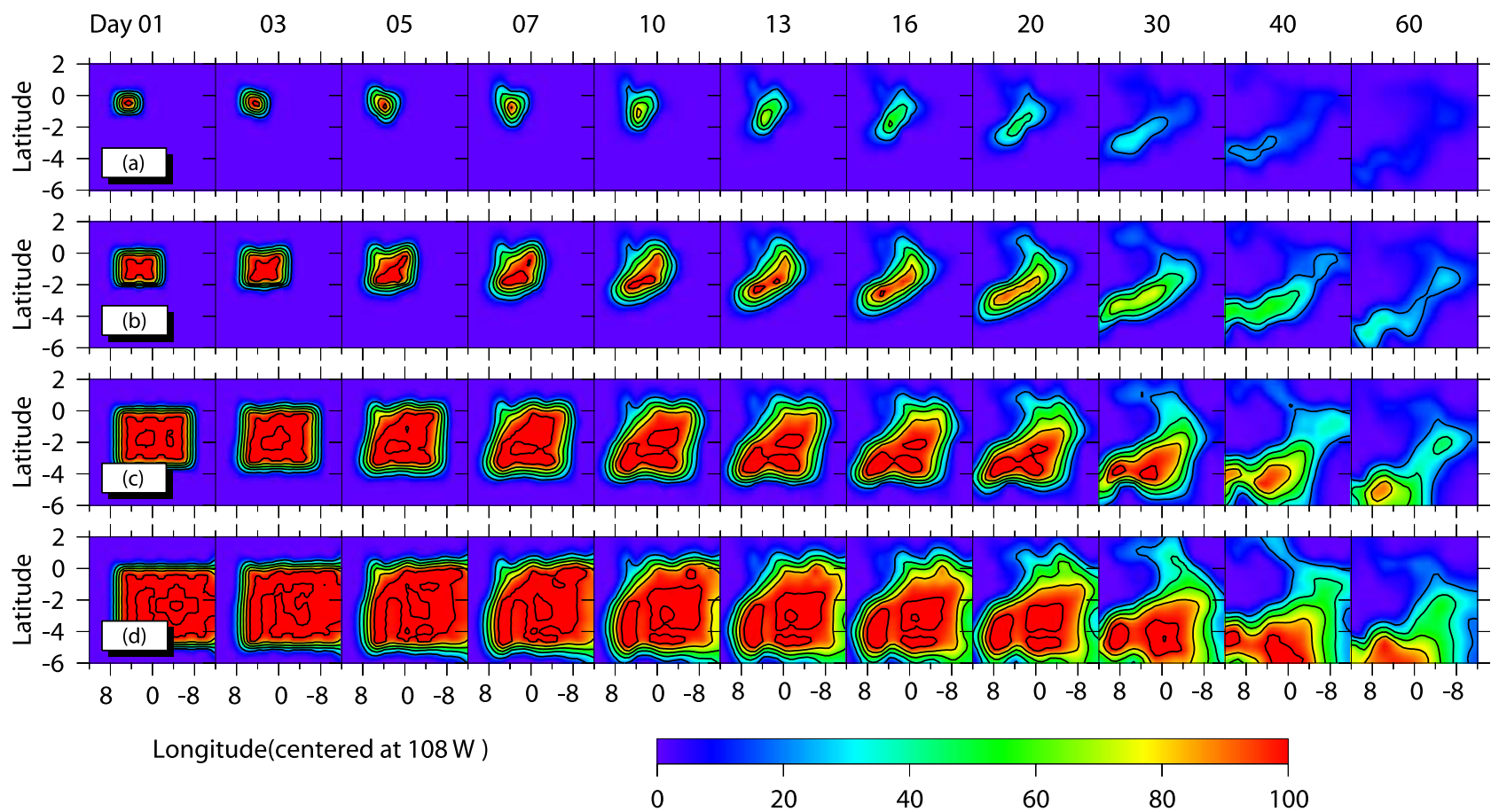

Figure 8. Temporal and spatial variations of the modeled surface inert tracer (IT) corresponding to different size of iron patch. (a) A $2 \times 2$ grid cells patch. (b) A $4 \times 4$ grid cells patch. (c) A $7 \times 7$ grid cells patch, which is the standard model simulation. (d) A $10 \times 10$ grid cells patch. IT field does not have a unit; the value is 100 inside the patch at the beginning of the iron enrichment.

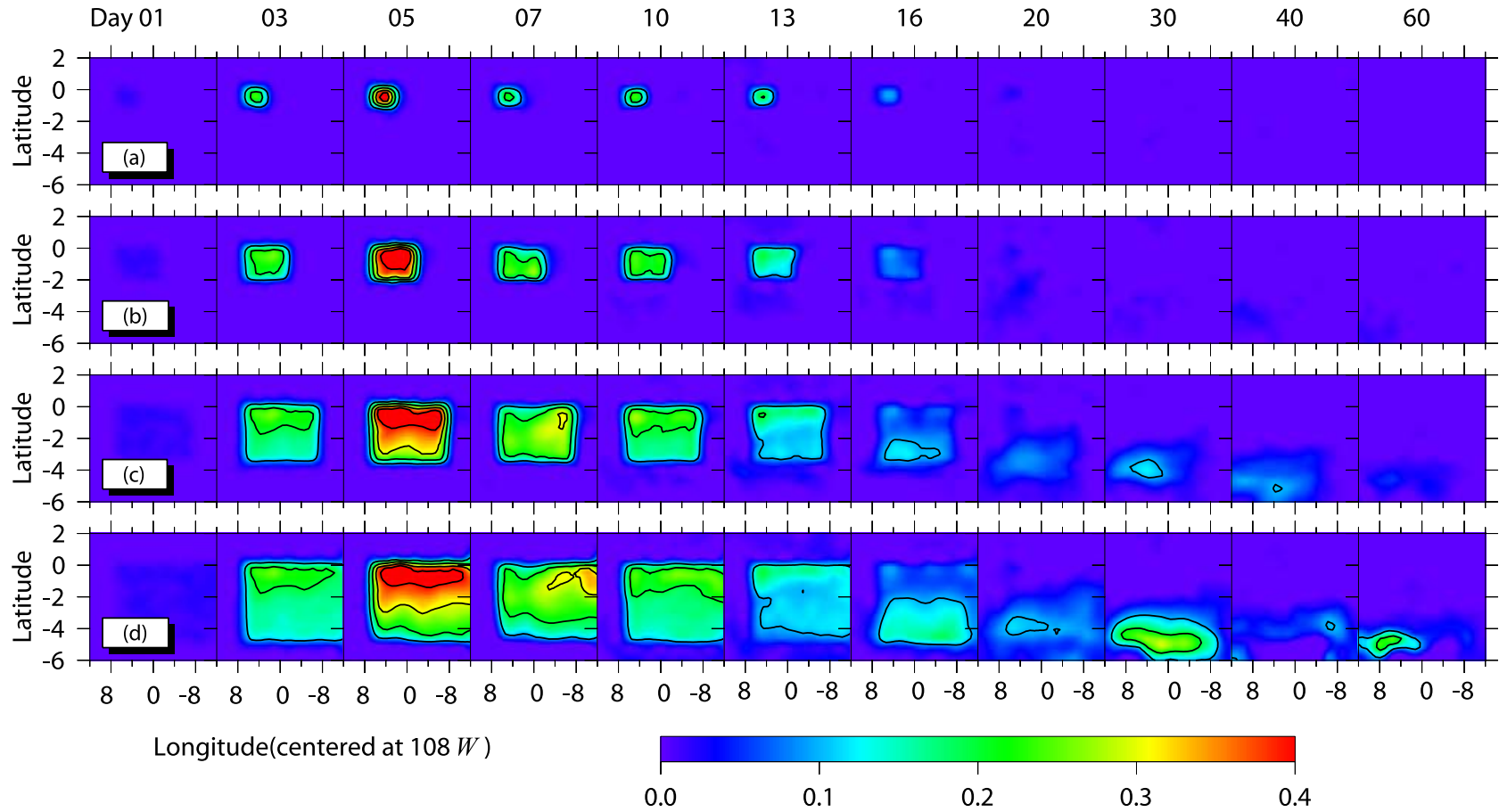

Figure 9. Temporal and spatial variations of the modeled surface phytoplankton anomaly corresponding to different size of iron patch. The phytoplankton anomaly due to iron addition is obtained from the difference between the "iron addition" and "ambient" (without iron) concentration, and the unit is $\mathrm{mmol} / \mathrm{m}^{3}$; red means positive, with phytoplankton increase due to iron enrichment. (a) A $2 \times 2$ grid cells patch. (b) A $4 \times 4$ grid cells patch. (c) A $7 \times 7$ grid cells patch, which is the standard model simulation. (d) A $10 \times 10$ grid cells patch. 

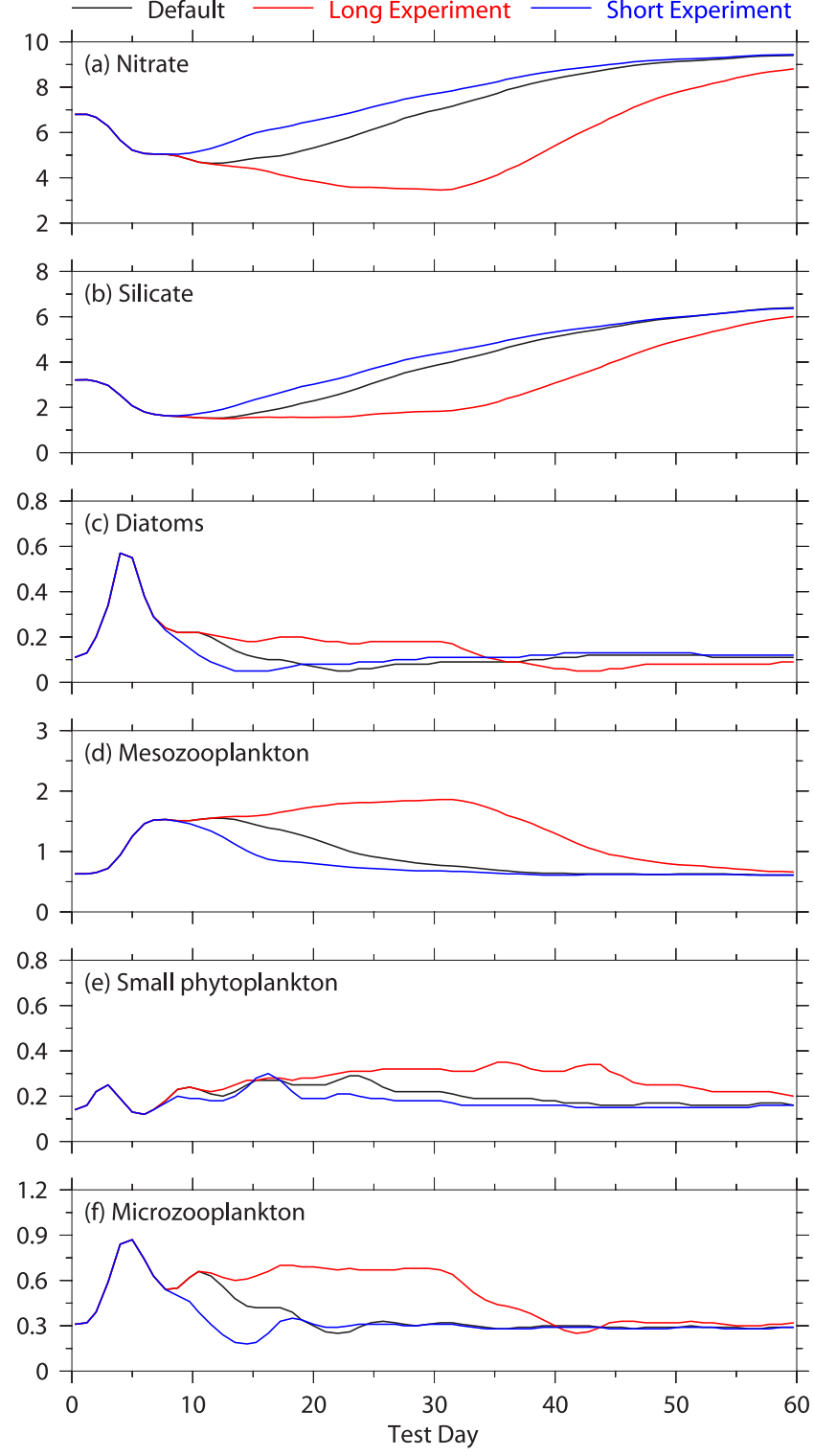

Figure 10. Modeled surface responses of nutrients and plankton as sensitivity simulations to the duration of iron fertilization. "Default" is the standard model simulation with iron fertilization (black line); "Long" (red line) experiment keeps the phytoplankton growth parameters $\left(\alpha, \mu 1_{\max }\right.$ and $\mu 2_{\max }$ ) inside the iron patch at the maximum value between day 3 and day 30 (day 3 to day 10 for the control run), then decreases linearly back to the normal values at day 40 (whereas the control run returns to the normal parameter value at day 20); "Short" (blue line) experiment keeps the maximum value of $\alpha, \mu 1_{\max }$ and $\mu 2_{\max }$ between day 3 and day 7 , then decreases linearly back to the normal values at day 12 . The modeled nutrients and plankton concentrations are averaged inside the iron patch, which is defined with the inert tracer in the model, and unit is $\mathrm{mmol} / \mathrm{m}^{3}$ for all six plots. influenced by advection and diffusion processes, which shows the center of the largest phytoplankton biomass increase is located in the southwest to the center of the original iron patch at day 60 . On the other hand, phytoplankton biomass increase disappears quickly after day 20 with the smallest patch experiment $(2 \times 2$ grid cells patch), which are due to the combination of zooplankton grazing and silicate limitation inside the patch. For the larger patch experiments $(7 \times 7$ and $10 \times 10$ grid cells patch), amount of phytoplankton biomass increase stimulated by iron is much greater than the smaller patch experiments, which allows more phytoplankton being retained within the patch. The patch dilution effect is more pronounced in the smaller patch experiments than the larger patches. Also, the larger patches tend to have more nutrients than smaller patch experiments, which could continue to fuel the phytoplankton bloom. In summary, with a larger size of the iron patch, the model tends to produce a broader spatial extent and longer lasting phytoplankton bloom. However, such modeling results need to be confirmed with carefully designed in situ field studies. Also, the current model resolution is relative coarse $\left(2^{\circ} \times 0.5^{\circ}\right)$ near the equator, which prevents us to conduct any model simulations with iron patch size smaller than $44,000 \mathrm{~km}^{2}$ $(2 \times 2$ grid point). A much finer model resolution (less than $10 \mathrm{~km}$ or so) will be needed in order to address the more detailed patch dynamics and their potential impact on nutrient drawdown and phytoplankton bloom dynamics.

\subsection{Duration of Iron Fertilization}

[30] Beside the size of iron patch affecting phytoplankton response, the duration of iron fertilization also influences the intensity and the period of phytoplankton bloom. We designed two model sensitivity simulations to address nutrients and plankton responses to different duration of iron fertilization. The first experiment is to keep the increase of phytoplankton growth parameters for a longer period than the default simulation. The $\alpha, \mu 1_{\max }$ and $\mu 2_{\max }$ inside the iron patch $(7 \times 7$ grid cells patch, the standard iron patch) stay at the maximum value between day 3 and day 30 (day 3 to day 10 for the default run), then decrease linearly back to the normal values at day 40 (whereas the default run returns to the normal parameter value at day 20). The first experiment is labeled as "Long." The second experiment is to shorten duration of parameter changes comparing to the default simulation, The $\alpha, \mu 1_{\max }$ and $\mu 2_{\max }$ inside the iron patch stay at the maximum value between day 3 and day 7 (day 3 to day 10 for the default run), then decrease linearly back to the normal values at day 12 (whereas the default run returns to the normal parameter value at day 20). The second experiment is labeled as "Short." With three model simulations, "Default," "Long," and "Short," we compare the modeled surface nutrients and plankton concentration inside the iron patch (Figure 10). For the first seven days with all three experiments, the model produces the same results, the intensity, the timing of diatom increase, and initial drawdown of nutrients. This is because for the first seven days the same treatment of $\alpha, \mu 1_{\max }$ and $\mu 2_{\max }$ inside the iron patch was applied for all three experiments. With longer duration of iron fertilization, the phytoplankton increase tends to last much longer than the other two 
experiments. The diatoms dominate the initial increase (red line in Figure 10c) and small phytoplankton becomes more abundant (red line in Figure 10e) at late phase of the experiment. $\mathrm{NO}_{3}$ and $\mathrm{Si}(\mathrm{OH})_{4}$ drawdown also last longer with the "Long" experiment (red line in Figures 10a and $10 \mathrm{~b}$ ), and both nutrients reach the minimum value inside the iron patch at day 30 when the maximum drawdown occurs. Both micro- and meso-zooplankton increase substantially with the "Long" experiment comparing to the other two, red line in Figures 10d and 10f. The significant increase of the mesozooplankton biomass enhances the grazing pressure on diatoms and microzooplankton that prevents further accumulation of diatom biomass at later phase in spite of higher growth rate due to iron addition. The reducing the grazing pressure on small phytoplankton by the microzooplankton results more small phytoplankton biomass accumulation even after day 50 since the beginning of the experiment. With shorter duration of iron fertilization, the plankton biomass tends to return to the "normal" conditions much quicker. Both $\mathrm{NO}_{3}$ and $\mathrm{Si}(\mathrm{OH})_{4}$ reestablish the "normal" concentration (around day 40 or so) at slower rate owing to the fact that circulation and mixing would have to bring both nutrients from below and surrounding unfertilized waters.

[31] Comparing all three experiments in terms of duration of iron fertilization, longer duration with iron addition tends to prolong phytoplankton growth, but higher zooplankton grazing pressure prevents significant phytoplankton biomass accumulation. Shorter period of iron fertilization generates the same magnitude of initial phytoplankton bloom, but it returns to the normal conditions very quickly. This indicates the short-term iron fertilization experiment has minimum impact because the physical and biological systems can recovery from the short perturbation quickly [Barber and Hiscock, 2006].

\subsection{Iron-Enhanced Export Fluxes}

[32] While there is little discussion remaining over whether iron limits production in HNLC regions, there is still significant debate over how much particulate organic carbon and biogenic silica can be exported to depth as a result of enhanced phytoplankton and zooplankton production [Coale et al., 1996; Charette and Buesseler, 2000; de Baar et al., 2005]. Iron fertilization experiments are typically limited to about 30 days owing to ship constraints. Ecosystem and carbon modeling, on the other hand, provide alternative means to address potential enhancement of particular organic carbon and biogenic silica export due to iron addition over longer timescales. Traditionally, threedimensional physical-biological models treat the biogeochemical processes below the euphotic zone with a simplified "Martin Curve," by which the depth-distribution flux of particulate organic material (POM) is specified using an empirical function from Martin et al. [1987], which converts the sinking POM into inorganic nutrients. A recent modeling paper by Armstrong et al. [2002] challenged the "Martin Curve" approach, suggesting that although the "Martin Curve" constrains the remineralization process of POC, it may not be appropriate for predicting other sinking materials, such as biogenic silica associated with diatom blooms and other "ballast" minerals. In order to track biogenic silica export and associated carbon in our $\mathrm{Fe}$ fertilization experiments, we did not use the "Martin Curve" approach, but treated $\mathrm{Si}$ regeneration of biogenic silica with a temperature- and depth-dependent rate, as described by Jiang et al. [2003] and Fujii and Chai [2005].

[33] The larger-size particles tend to sink faster, and therefore dominate the amount of material exported. Ironinduced increases in diatom and mesozooplankton biomass contribute to an increase of the large and siliceous detritus pool, consisting of fecal pellets and ungrazed diatoms. The area-averaged (over the entire iron patch) siliceous detritus (DSi) anomaly field is obtained from the difference between the "iron addition" and "ambient" (without iron) concentrations (Figure 11). The DSi anomaly starts with a positive value near the surface after day 5, and then gradually increases in value with depth as time progresses. The DSi anomaly reaches a maximum around day 13 at $75 \mathrm{~m}$ depth, which is still in the euphotic zone. It takes significantly longer period for the DSi anomaly to reach depths below the euphotic zone. At $200 \mathrm{~m}$ the DSi anomaly reaches a maximum about 30 days after the beginning of the experiment. The depth-time distribution of the DSi anomaly field is almost linear with a sinking speed of $9 \mathrm{~m} \mathrm{~d}^{-1}$, which is very close to the detrital $\mathrm{Si}$ sinking velocity of $10 \mathrm{~m} \mathrm{~d}^{-1}$ used in the model [Chai et al., 2002].

[34] The modeled DSi anomaly field indicates that it would take more than 30 days to detect any significant export out of the euphotic zone in the equatorial Pacific. In high-latitude HNLC regions, such as the Southern Ocean and the North Pacific, where water temperature is lower and the community response to iron addition is slower, it may take significantly longer time than 30 days for any export to take place [Fujii et al., 2005]. On the other hand, once an iron induced phytoplankton bloom starts, the lower temperature at high latitude would slow down biogenic silica dissolution and increase sinking rate and flux owing to greater biogenic silica ballasting effects [Armstrong et al., 2002]. Technical and logistical constraints have prevented accurate detection and measurement of exported particulate organic carbon and biogenic silica during in situ iron fertilization experiments [Coale et al., 1996; Boyd et al., 2000; Tsuda et al., 2003; de Baar et al., 2005]. Developing and improving more comprehensive interdisciplinary models should help to fill the gaps of observational data [Johnson et al., 2002].

\subsection{Iron and $\mathrm{Si} / \mathrm{N}$ Uptake Ratio by Diatoms}

[35] The modeled responses of diatom productivity and biogenic silica export to iron enrichment show a complicated interplay between iron and silicon cycle in the equatorial Pacific. In real world experiments, when HNLC surface waters are fertilized with iron, diatoms are observed to grow with abnormally low $\mathrm{Si} / \mathrm{N}$ ratios, primarily because of increased organic-matter content [Takeda, 1998; Hutchins and Bruland, 1998; Franck et al., 2000]. Reviewing in situ and laboratory experiments, Martin-Jezequel et al. [2000] found that these ratios sensitive to ambient conditions (light, temperature, nutrients and iron). Using a cell quota modeling approach, Flynn and Martin-Jezequel [2000] 


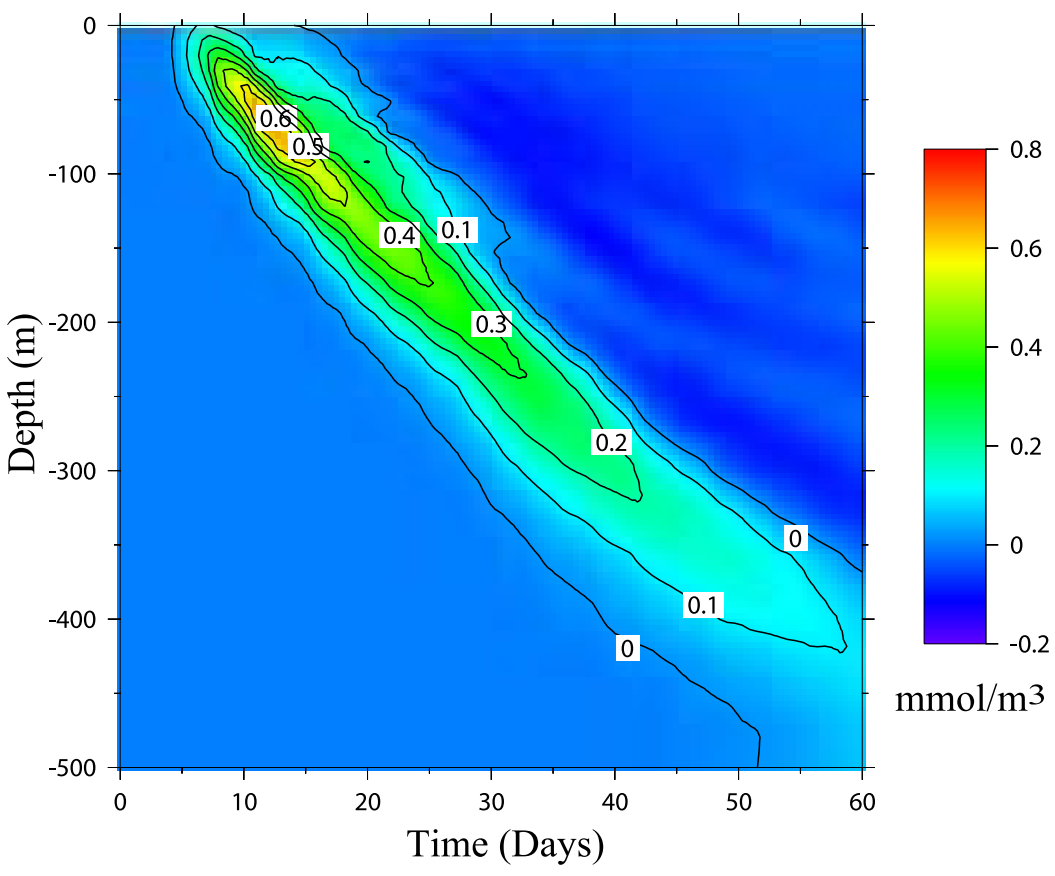

Figure 11. Modeled export detritus Si anomaly due to Fe fertilization, which is obtained from the difference between Fe fertilization and normal. The export of detritus Si clearly shows a time-delayed response with depth; for example, the maximum signal of the sinking detritus Si materials at $200 \mathrm{~m}$ is around day 30 .

found the $\mathrm{C}$ quota of cells (and therefore the $\mathrm{C}: \mathrm{N}, \mathrm{C}: \mathrm{Si}$ ratios) responsive to different levels of $\mathrm{Si}$ - and $\mathrm{N}$-stress. While the simple model used here ignores these details of diatom metabolism, the enhanced organic content found in situ suggests a more significant export than even that observed in the model here.

[36] Jiang and Chai [2004] used the same physicalbiological model to investigate relationship between iron level and $\mathrm{N} / \mathrm{Si}$ uptake ratios by diatoms in the equatorial Pacific. The increase of iron supply in the equatorial Pacific would decrease $\mathrm{Si} / \mathrm{N}$ uptake ratio by diatoms, which results in supporting higher organic production. However, the reduction of $\mathrm{Si} / \mathrm{N}$ uptake ratio by diatoms compensates the increase of diatom growth so that the biogenic silica (BSi) production remains largely unchanged. The high organic production also tends to drive the system into nitrate depletion. Jiang and Chai [2004] reached same conclusions with permanent iron replete or deplete conditions. Changes of $\mathrm{Si} / \mathrm{N}$ and $\mathrm{Si} / \mathrm{C}$ uptake ratios by diatoms during different phases of short-term iron fertilization experiments need to be considered and incorporated into future iron and silicate based models.

[37] Dugdale et al. [2004] used the 1-D CoSINE model to address the phytoplankton community changes in response to silicate supply to the euphotic zone, and they did so without considering changes of iron effects (i.e., fixed photosynthetic efficiency and $\mathrm{Si} / \mathrm{N}$ uptake ratio by diatoms). By comparing the central Pacific core of opal accumulation with the atmospheric $\mathrm{CO}_{2}$ concentration from the Vostok core, Dugdale et al. [2004] found that for most of the last glacial cycle, opal deposition and atmospheric $\mathrm{CO}_{2}$ vary together rather than in opposition as would be expected if increased diatom productivity resulted in decreased atmospheric $\mathrm{CO}_{2}$. This direct variation in opal deposition and atmospheric $\mathrm{CO}_{2}$ has an analog in the 1-D CoSINE model of the equatorial ecosystem where a phase occurs in which decreasing source $\mathrm{Si}(\mathrm{OH})_{4}$ concentration results in decreased surface $\mathrm{NO}_{3}$ and $\mathrm{TCO}_{2} . \mathrm{NO}_{3}$ and $\mathrm{TCO}_{2}$ decrease because the phytoplankton community becomes less rich in diatoms. A decrease in the larger primary producers in turn alters the mesozooplankton grazing pressures between diatoms and microzooplankton. Non $\mathrm{Si}(\mathrm{OH})_{4}$-using phytoplankton, released from microzooplankton grazing pressure take up the residual $\mathrm{NO}_{3}$ as well as additional residual $\mathrm{TCO}_{2}$ flux and reduce $\mathrm{CO}_{2}$ flux to the atmosphere [Dugdale et al., 2004]. Such modeled long-term behaviors are similar to the short-term model responses to iron injection in the equatorial Pacific (e.g., Figure 5).

[38] In summary, linking silicon cycle and effects of iron is crucial for understanding ecosystem dynamics in the equatorial Pacific and other HNLC regions. Improving physical-biogeochemical models would advance our understanding on the role of silicate and iron in determining global carbon cycle for the present conditions as well as glacial and interglacial changes.

\section{Conclusions}

[39] Using a three-dimensional physical-biogeochemical model we have investigated the modeled responses of diatom productivity and biogenic silica export to iron enrichment in the eastern equatorial Pacific, and compared the model 
simulation with in situ (IronEx II) iron fertilization results. The main results from this modeling study are as follows.

[40] 1. Inside the iron patch created in the model, the vertically integrated $\mathrm{Chl} a$ and primary production increased by about threefold 5 days after the start of the experiment, similar to that observed in the IronEx II experiment. Diatoms contribute to the initial increase of the total phytoplankton biomass, but decrease sharply after 10 days because of mesozooplankton grazing.

[41] 2. The modeled surface maximum drawdown of nutrients and $\mathrm{TCO}_{2}$ due to iron addition are $3.8 \mathrm{mmol} / \mathrm{m}^{3}$ for $\mathrm{NO}_{3}, 2.7 \mathrm{mmol} / \mathrm{m}^{3}$ for $\mathrm{Si}(\mathrm{OH})_{4}$, and $22.4 \mathrm{mmol} / \mathrm{m}^{3}$ for $\mathrm{TCO}_{2}$. The observed maximum drawdown of nutrients and $\mathrm{TCO}_{2}$ during the IronEx II experiment are $4.0 \mathrm{mmol} / \mathrm{m}^{3}$ for $\mathrm{NO}_{3}, 4.0 \mathrm{mmol} / \mathrm{m}^{3}$ for $\mathrm{Si}(\mathrm{OH})_{4}$, and $27.0 \mathrm{mmol} / \mathrm{m}^{3}$ for $\mathrm{TCO}_{2}$. The modeled surface nutrients (silicate and nitrate) and $\mathrm{TCO}_{2}$ concentration agree well with the IronEx II observations and climatological values for the region.

[42] 3. The modeled depth-time distribution of sinking biogenic silica (BSi) indicates that it would take more than 30 days after iron injection to detect any significant BSi export out of the euphotic zone.

[43] 4. Model sensitivity studies showed that a larger size of the iron patch tends to produce a broader extent and longer-lasting phytoplankton blooms. Longer duration prolongs phytoplankton growth, but higher zooplankton grazing pressure prevents significant phytoplankton biomass accumulation.

[44] 5. With the same treatment of iron fertilization in the model, lowering mesozooplankton grazing rate generates much stronger diatom bloom, but it is terminated by $\mathrm{Si}(\mathrm{OH})_{4}$ limitation after the initial rapid increase. Increasing mesozooplankton grazing rate, the diatom increase due to iron addition stays at minimum level, but small phytoplankton tend to increase.

[45] Acknowledgments. This research was supported by a NSF grant (OCE-0137272) to F. Chai, and a NASA grant (NAG5-9348) to F. Chai, R. T. Barber, and Y. Chao. F. Chai also thanks NSFC (contract 90211021) for support for his international travel.

\section{References}

Anderson, L. A., and J. L. Sarmiento (1994), Redfield ratios of remineralization determined by nutrient data analysis, Global Biogeochem. Cycles, 8(1), 65-80.

Armstrong, R. A., C. Lee, J. I. Hedges, S. Honjo, and S. G. Wakeham (2002), A new, mechanistic model for organic carbon fluxes in the ocean, based on the quantitative association of POC with ballast minerals, Deep Sea Res., Part II, 49, 219-236.

Barber, R. T. (1992), Introduction to the WEC88 cruise: An investigation into why the equatorial is not greener, J. Geophys. Res., 97, 609-610.

Barber, R. T., and M. R. Hiscock (2006), A rising tide lifts all phytoplankton: Growth response of other phytoplankton taxa in diatom-dominated blooms, Global Biogeochem. Cycles, 20, GB4S03, doi:10.1029/ 2006GB002726.

Barber, R. T., F. Chai, S. T. Lindley, and R. R. Bidigare (1996), Regulation of equatorial primary production, in Global Fluxes of Carbon and Related Substances in the Coastal Sea-Ocean-Atmosphere System, edited by I. Koike, pp. 283-290, Sci. Counc. of Jpn., Tokyo.

Bidigare, R. R., and M. E. Ondrusek (1996), Spatial and temporal variability of phytoplankton pigment distributions in the central equatorial Pacific Ocean, Deep Sea Res., Part II, 43, 809-833.

Boyd, P. W., et al. (2000), A mesoscale phytoplankton bloom in the polar Southern Ocean stimulated by iron fertilization, Nature, 407, 695-702.

Brzezinski, M. A., and D. N. M. Nelson (1995), The annual silica cycle in the Sargasso Sea near Bermuda, Deep Sea Res., Part I, 42, 1215-1237.
Buesseler, K. O., and P. W. Boyd (2003), Will ocean fertilization work?, Science, 300, 67-68

Chai, F., S. T. Lindley, and R. T. Barber (1996), Origin and maintenance of a high $\mathrm{NO}_{3}$ condition in the equatorial Pacific, Deep Sea Res., Part II, 43, $1031-1064$.

Chai, F., S. T. Lindley, J. R. Toggweiler, and R. T. Barber (1999), Testing the importance of iron and grazing in the maintenance of the high nitrate condition in the equatorial Pacific Ocean, a physical-biological model study, in The Changing Ocean Carbon Cycle, Int. Geosphere-Biosphere Programme Book Ser., vol. 5, edited by R. B. Hanson, H. W. Ducklow, and J. G. Field, pp. 156-186, Cambridge Univ. Press, New York.

Chai, F., R. C. Dugdale, T.-H. Peng, F. P. Wilkerson, and R. T. Barker (2002), One dimensional ecosystem model of the Equatorial Pacific Upwelling System, Part I: Model development and silicon and nitrogen cycle, Deep Sea Res., Part II, 49, 2713-2745.

Chai, F., M. Jiang, R. T. Barber, R. C. Dugdale, and Y. Chao (2003), Interdecadal variation of the transition zone chlorophyll front: A physicalbiological model simulation between 1960 and 1990, J. Oceanogr., 59, $461-475$.

Charette, M. A., and K. O. Buesseler (2000), Does iron fertilization lead to rapid carbon export in the Southern Ocean?, Geochem. Geophys. Geosyst., 1(10), doi:10.1029/2000GC000069.

Chavez, F. P., K. R. Buck, K. H. Coale, J. H. Martin, G. R. DiTullio, N. A. Welshmeyer, A. C. Jacobson, and R. T. Barber (1991), Growth rates, grazing, sinking and iron limitation of equatorial Pacific phytoplankton, Limnol. Oceanogr., 36, 1816-1833.

Chavez, F. P., K. R. Buck, S. K. Service, J. Newton, and R. T. Barber (1996), Phytoplankton variability in the central and eastern tropical Pacific, Deep Sea Res., Part II, 43, 835-870.

Coale, K. H., et al. (1996), A massive phytoplankton bloom induced by an ecosystem-scale iron fertilization experiment in the equatorial Pacific Ocean, Nature, 383, 495-501.

Conkright, M. E., et al. (1998), World Ocean Database 1998, CD-ROM data set documentation, Internal Rep. 14, 111 pp., NOAA, Silver Spring, $\mathrm{Md}$

de Baar, H. J. W., et al. (2005), Synthesis of iron fertilization experiments: From the Iron Age in the Age of Enlightenment, J. Geophys. Res., 110, C09S16, doi:10.1029/2004JC002601.

Denman, K. L., and M. A. Pena (1999), A coupled 1-D biological/physical model of the northeast subarctic Pacific Ocean with iron limitation, Deep Sea Res., Part II, 46, 2877-2908.

Dugdale, R. C., and F. P. Wilkerson (1998), Silicate regulation of new production in the equatorial Pacific upwelling, Nature, 391, 270-273.

Dugdale, R. C., R. T. Barber, F. Chai, T.-H. Peng, and F. P. Wilkerson (2002), One dimensional ecosystem model of the equatorial Pacific upwelling system, Part II: Sensitivity analysis and comparison with JGOFS EqPac data, Deep Sea Res., Part II, 49, 2746-2762.

Dugdale, R. C., M. Lyle, F. P. Wilkerson, F. Chai, R. T. Barber, T.-H. Peng, and A. G. Wischmeyer (2004), The influence of equatorial diatom processes on Si deposition and atmospheric $\mathrm{CO}_{2}$ cycles at glacial/interglacial timescales, Paleoceanography, 19, PA3011, doi:10.1029/2003PA000929.

Dugdale, R. C., F. P. Wilkerson, F. Chai, and R. Feely (2006), Size fractioned nitrogen uptake measurements in the equatorial Pacific and confirmation of the low Si-high nutrient-low chlorophyll condition, Global Biogeochem. Cycles, 21, GB2005, doi:10.1029/2006GB002722.

Flynn, K. J., and V. Martin-Jezequel (2000), Modelling Si-N limited growth of diatoms, J. Plankton Res., 22(3), 447-472.

Franck, V. M., et al. (2000), Iron and silicic acid concentrations regulate $\mathrm{Si}$ uptake north and south of the Polar Frontal Zone in the Pacific Sector of the Southern Ocean, Deep Sea Res., Part II, 47, 3315-3338.

Frost, B. W., and N. C. Franzen (1992), Grazing and iron limitation in the phytoplankton stock and nutrient concentration: A chemostat analogue of the Pacific equatorial upwelling zone, Mar. Ecol. Prog. Ser., 83, 291303.

Fujii, M., and F. Chai (2005), Effects of biogenic silica dissolution on silicon cycling and export production, Geophys. Res. Lett., 32, L05617, doi:10.1029/2004GL022054

Fujii, M., N. Yoshie, Y. Yamanaka, and F. Chai (2005), Simulated biogeochemical responses to iron enrichments in three high nutrient, low chlorophyll (HNLC) regions, Prog. Oceanogr., 64, 307-324, doi:10/1016 j.pocean.2005.02.017

Gnanadesikan, A. (1999), A global model of silicon cycling: Sensitivity to eddy parameterization and dissolution, Global Biogeochem. Cycles, 13(1), 199-220.

Gnanadesikan, A., J. L. Sarmiento, and R. D. Slater (2003), Effects of patchy ocean fertilization on atmospheric carbon dioxide and biological productivity, Global Biogeochem. Cycles, 17(2), 1050, doi:10.1029/ 2002 GB001940. 
Hutchins, D. A , and K. W. Bruland (1998), Iron-limited diatom growth and $\mathrm{Si}: \mathrm{N}$ uptake ratios in a coastal upwelling regime, Nature, 393, 561-564.

Jiang, M.-S., and F. Chai (2004), Iron and silicate regulation on new and export production in the equatorial Pacific: A physical-biological model study, Geophys. Res. Lett., 31, L07307, doi:10.1029/2003GL018598.

Jiang, M.-S., and F. Chai (2005), Physical and biological controls on the latitudinal asymmetry of surface nutrients and $\mathrm{pCO}_{2}$ in the central and eastern equatorial Pacific, J. Geophys. Res., 110, C06007, doi:10.1029/ 2004JC002715.

Jiang, M.-S., F. Chai, R. C. Dugdale, F. Wilkerson, T.-H. Peng, and R. T. Barber (2003), A nitrate and silicate budget in the equatorial Pacific Ocean A coupled biological-physical model study, Deep Sea Res., Part II, 50 , $2971-2996$

Johnson, K. S., J. K. Moore, and W. O. Smith (2002), Workshop highlights iron dynamics in ocean carbon cycle, Eos Trans. AGU, 83(43), 482-484.

Ku, T. L., S. Luo, M. Kusakabe, and J. K. B. Bishop (1995), ${ }^{228}$ Ra-derived nutrient budgets in the upper equatorial Pacific and the role of "new" silicate in limiting productivity, Deep Sea Res., Part II, 42, 479-497.

Landry, M. R., J. Constantinou, and J. Kirshtein (1995), Microzooplankton grazing in the central equatorial Pacific during February and August, 1992, Deep Sea Res., Part II, 42, 657-672.

Landry, M. R., et al. (1997), Iron and grazing constraints on primary production in the central equatorial Pacific: An EqPac synthesis, Limnol. Oceanogr., 42, 405-418

Landry, M. R., et al. (2000), Iron cycling and nutrient-limitation patterns in surface waters of the World Ocean, Mar. Ecol. Prog. Ser, 201, 27-42.

Law, C. S., A. J. Watson, M. I. Liddicoat, and T. Stanton (1998), Sulphur hexafluoride as a tracer of biogeochemical and physical processes in an open-ocean iron fertilization experiment, Deep Sea Res., Part II, 45 , 977-994.

Levitus, S., and T. P. Boyer (1994), World Ocean Atlas 1994, vol. 4 Temperature, NOAA Atlas NESDIS, vol. 4, 129 pp., NOAA, Silver Spring, Md.

Levitus, S., M. E. Conkright, J. L. Reid, R. G. Najjar, and A. Mantyla (1993), Distribution of nitrate, phosphate and silicate in the world oceans, Prog. Oceanogr., 31(3), 245-273.

Levitus, S., R. Burgett, and T. P. Boyer (1994), World Ocean Atlas 1994, vol. 3, Salinity, NOAA Atlas NESDIS, vol. 3, 111 pp., NOAA, Silver Spring, Md.

Li, X., Y. Chao, J. C. McWilliams, and L.-L. Fu (2001), A comparison between two vertical mixing schemes in a Pacific OGCM, J. Clim., 14(7), $1377-1398$

Lindley, S. T., et al. (1995), Phytoplankton photosynthesis parameters along $140^{\circ} \mathrm{W}$ in the equatorial Pacific, Deep Sea Res., Part II, 42, 441-463.

Lindley, S. T., and R. T. Barber (1998), Phytoplankton response to natural and artificial iron addition, Deep Sea Res., Part II, 45, 1135-1150.

Martin, J. H. (1990), Glacial-interglacial $\mathrm{CO}_{2}$ change: the iron hypothesis, Paleoceanography, 5(1), 1-13.

Martin, J. H., G. A. Knauer, D. M. Karl, and W. W. Broenkow (1987), VERTEX: Carbon cycling in the northeast Pacific, Deep Sea Res., 34 $267-285$
Martin, J. H., et al. (1994), Testing the iron hypothesis in ecosystems of the equatorial Pacific Ocean, Nature, 371, 123-129.

Martin-Jezequel, V., M. Hildebrand, and M. A. Brzezinski (2000), Silicon metabolism in diatoms: Implications for growth, J. Phycol., 36, 821840 .

Monger, B. C., et al. (1997), Frequency response of a simple food-chain model with time-delayed recruitment: Implication for abiotic-biotic coupling, in Structured Population Models in Marine, Terrestrial and Freshwater Systems, edited by S. Tuljapurkar and H. Caswell, pp. 433-450, Chapman and Hall, New York.

Nelson, D. M., J. J. Goering, and D. W. Boisseau (1981), Consumption and regeneration of silicic acid in three coastal upwelling systems, in Coastal Upwelling, Coastal Estuarine Stud., vol. 1, edited by F. A. Richards, pp. 242-256, AGU, Washington, D. C.

Nelson, D. M., P. Treguer, M. A. Brzezinski, A. Leynaert, and B. Queguiner (1995), Production and dissolution of biogenic silica in the ocean: Revised global estimates, comparison with regional data and relationship to biogenic sedimentation, Global Biogeochem. Cycles, 9(3), 359-372.

Ragueneau, O., et al. (2000), A review of the Si cycle in the modern ocean: Recent progress and missing gaps in the application of biogenic opal as a paleoproductivity proxy, Global Planet. Change, 26, 317-365.

Ridgwell, A. J. (2000), Climatic effect of Southern Ocean Fe fertilization: Is the jury still out?, Geochem. Geophys. Geosyst., 1(12), doi:10.1029/ 2000GC000120.

Smetacek, V. (1985), The annual cycle of Kiel bight plankton: A long term analysis, Estuaries, 8, 145-157.

Steinberg, P. A., et al. (1998), Carbonate system response to iron enrichment, Mar. Chem., 62, 31-43.

Takeda, S. (1998), Influence of iron availability on nutrient consumption ratio of diatoms in oceanic waters, Nature, 393, 774-776.

Tsuda, A., et al. (2003), A mesoscale iron enrichment in the western subarctic Pacific induces a large centric diatom bloom, Science, 300, 958961

R. T. Barber, Nicholas School of the Environment and Earth Sciences Marine Laboratory, Duke University, 135 Duke Marine Lab Road, Beaufort, NC 28516, USA

F. Chai, School of Marine Sciences, 5706 Aubert Hall, University of Maine, Orono, ME 04469-5706, USA. (fchai@maine.edu)

Y. Chao, Jet Propulsion Laboratory, California Institute of Technology, 4800 Oak Grove Drive, Pasadena, CA 91109, USA.

F. Chavez, Monterey Bay Aquarium Research Institute, P.O. BOX 628, 7700 Sandholdt Rd., Moss Landing, CA 95039-0628, USA.

R. C. Dugdale, Romberg Tiburon Center, San Francisco State University, 3152 Paradise Drive, Tiburon, CA 94920, USA.

M.-S. Jiang, Environmental, Earth and Ocean Sciences Department, University of Massachusetts Boston, 100 Morrissey Blvd., Boston, MA 02125, USA. 